\title{
The Extent and Impact of Intellectual Capital Research: A Two Decade Analysis
}

\author{
Umesh Bamel \\ Organization Behaviour and Human Resources, International Management Institute New Delhi, New \\ Delhi, India \\ Vijay Pereira \\ Neoma Business School, Reims Campus, Reims, France \\ Manlio Del Giudice \\ Management University of Rome Link Campus University, Lazio, Italy and National Research \\ University Higher School of Economic, Moscow, Russian Federation, and \\ Yama Temouri \\ Khalifa University of Science and Technology, Abu Dhabi, United Arab Emirates and Aston \\ University, Birmingham, UK
}

\begin{abstract}
Purpose - This paper examines the leading publication trends including the extent and impact of intellectual capital research in the Journal of Intellectual Capital (JIC) over a two-decade period (2000 to 2020). The bibliometric analysis offers the description of publications trends such as key authors, articles, cited references, institutions and countries-in other words the extent and impact in the field. This paper also presents the knowledge structure (including conceptual, intellectual and social structures) of JIC i.e. prominent themes, co-citation and bibliographic networks.
\end{abstract}

Design/methodology/approach - In order to achieve research objectives, we collected the bibliographic information of the articles published in JIC for the period 2000 to 2020 from the Scopus database on 11.04.2020. The bibliographic information of 737 documents were analysed using to open source analysis tool i.e. bibliometrics package in $\mathrm{r}$ software and VOSviewer. These tools were used to create the graphical visualization of bibliographic data on basis of co-occurrence, co-citation and bibliographic coupling.

Findings - The results show that the journal is progressing in terms of publication quantity and reputation in the field. To date, 737 documents have been published in JIC, which includes 659 research articles, 8 editorials, 7 notes and 63 review papers. This paper also portrays the author impact list in terms of most impactful articles published in JIC. Country-wise Italy, Australia, and USA exert most influence on JIC scholarship.

Originality/value- Bibliographic analysis offers a comprehensive understanding of past trends and presents the future direction of a journal.

Keywords: Bibliometrix, Bibliometric, Citation analysis, Intellectual capital disclosure, Intellectual Capital reporting, Journal of Intellectual Capital, Knowledge Management, Scopus, $h$-index 


\section{Introduction}

The journal of intellectual capital (JIC) is a double-blind peer reviewed leading international journal within the intellectual capital domain. JIC primarily publishes research on various topicalities of intellectual capital within the context of a modern knowledge economy (Bongiovanni et al., 2020; Oliveira et al., 2020; Popkova and Sergi, 2020). JIC is indexed in journal citation report of Web of Science (WoS) with an impact factor of 3.744 and in Scopus with a CiteScore of 6.48. These index values place JIC as a journal in the top quartile in business and management categories. Rory L Chase (MD, Teleos, UK) started JIC in the year 2000 and the journal published four issues annually, with the number of publication frequency increasing to five issues in 2018 and further to six issues in 2019. Since its inception, the growth and reputation of JIC has increased immensely and JIC has thus witnessed a huge influx of submissions. JIC is a leading and distinguished title and has a strong impact on the intellectual capital knowledge base (de Pablos and Edvinsson, 2020; Kim et al., 2020).

Currently, Merrill Warkentin leads the journal (editor) with six editorial sections: Bradley S. Trinkle and Ofir Turel, Business research method; Xin (Robert) Luo and Bo Xu, Emerging Topics in Intellectual Capital Research; Valentina Cillo and Stefano Fontana, Intellectual Capital, Firm Evaluation, Organization Studies, and Sustainability; Stefano Bresciani, Knowledge, Technology and Innovation Management; Jacques Ophoff and Karen Renaud, Securing the Organization's Knowledge and Information; Marco Romano and Francesco Schiavone, Strategic Management, Human Resource Management, Learning Studies. Veronica Scuotto is assisting the journal editorial leadership.

It is evident that journals usually publish a review, a special issue or an editorial to celebrate anniversaries (Van Fleet et al., 2006; Meyer and Winer, 2014). Recently there has been an interesting trend i.e. publishing a bibliometric review of the journal whenever a journal reaches or achieves a publishing milestone. Some of these are noted here: a bibliometric overview of Journal of Business Research (Merigó et al, 2015); fifty years of European Journal of Marketing (Martínez-López et al., 2018); fifty years of Financial Review (Baker et al., 2020), as examples. Further recent examples of journals published such review articles have been in the British Journal of Management (Pereira et al., 2020), who analysed three decades of emerging market research, providing future research directions; the Asia Pacific Journal of Management (Budhwar et al., 2019), who reviewed the state of HRM in the Middle East, identifying key challenges and providing future research agenda; the Journal of Business Research on outsourcing and offshoring decision making (Pereira et al., 2019).

Such reviews of a journal offer a comprehensive evaluation in terms of its publication trends and patterns (Martínez-López et al., 2018; Merigo et al., 2015). It also aims to identify popular themes, scholars, department/universities/countries- which contribute maximum publications in a domain i.e. the extent and impact in a particular field of study. These aspects have thus led to a surge in such type of review publications (e.g. Bamel et al., 2020, Kumar et al., 2020). In addition, bibliometric analysis helps in visualising the structures of a research field objectively i.e. clustering and citation patterns of related documents (Vogel et al, 2020). Thus, bibliometric method has gained widespread attention in recent time and is considered as more objective approach for reviewing a knowledge domain and base (Vogel et al, 2020). JIC has recently celebrated its $20^{\text {th }}$ anniversary and is now 2 decades old, during which it has published 737 research documents. This has been the key motivation to thus develop this study, whose 
objective is to describe the general publication trends and knowledge structure in JIC. This review piece looks at the past (i.e. evolution and historical progression of intellectual capital knowledge base), the present (i.e. current trends), and the future (i.e. emerging trends and future course of development in the intellectual capital research base in JIC). More specifically, this study aims to answer following two key research questions:

$R Q$ 1: what is general description and publication trend in JIC in term of top ranked authors, top cited articles, top publishing institutes and countries, and top ranked key words?

$R Q$ 2: what is the conceptual (2 a), intellectual (2 b) and social (2 c) structure of the extent and impact of intellectual capital knowledge in JIC?

In order to answer these questions, we analysed the quantitative properties such as citation information and citation publication structure of the documents that have been published in JIC. For structuring the knowledge domain of the journal, this paper presents keyword cooccurrence network, time overlay visualization of key words, co-citation and bibliographic networks and collaboration network among authors, institutes and countries. This type of analysis of JIC would help in assessing its contribution within the intellectual capital knowledge domain, as it identifies prominent as well as emerging research themes, that will help understand the future direction of research in this domain (Kumar et al. 2020).

The paper is structured as follows. The next section of the study details the methodology of the paper, followed by results and discussion. The paper concludes by summarizing the contributions as well as the limitations of the paper.

\section{Method}

The principle objective of this paper is to present a quantitative review of the intellectual capital knowledge published in JIC in last two decades. To achieve this objective, bibliometric information of documents was retrieved and analysed using Bibliometrix R package (Aria \& Cuccurullo, 2017) and VOSviwer (Van Eck et al., 2010). The data search and retrieval process and the methodology are discussed in detail below. For data retrieval, we followed the established protocols for systematic literature review (e.g. Christofi et al., 2019; Vrontis \& Christofi, 2019).

\subsection{Data search, retrieval and sample}

We used bibliometric indicators such as total number of publications, total citations, $\mathrm{h}$ index, link strength etc. (Garfield, 1955, Bamel et al., 2020). Usually, bibliometric information of research articles is retrieved from Web of Science (WoS) and Scopus databases. In this study, we retrieved this information from Scopus. Scopus database is termed as more comprehensive abstract and citation database (Bamel et al. 2020). In the search bar, we searched for Journal of Intellectual Capital in "source title" on 09.04.2020. The initial search yielded us with 1136 documents from Journal of Intellectual Capital (JIC) and International Journal of Learning and Intellectual Capital (IJLIC). Since, focus of this paper was to review JIC knowledge base, we limited our search to JIC. This refinement yielded 737 documents published in JIC from 2000 to 2020. These 737 documents included 659 articles, 8 editorials, 7 research notes and 63 review articles. These articles were published by 1189 authors (165 single authors and 1024 multi-author). The other bibliometric indicators such as collaboration index of the data set was 1.96; documents per author was 0.62 ; authors per document was 1.61 ; and co-authorship per 
document was 2.26. These documents have 39.72 average citation per document with 1202 authors' keywords.

\subsection{Bibliometric methodology and data analysis}

Originally, the bibliometric methodology was introduced as a technique in library science as it provides a general overview of a set of documents using bibliometric indicators information (Garfield, 1955, Pritchard, 1969). This study considers the number of publications by an author, organization, country; number of citations, $\mathrm{h}$ index etc., to analyse general research trends, authors, universities, keywords, publication and citation structure, temporal evolution- to name a few. Such analyses (journal specific analysis) are gaining interest and acknowledgement in almost all field of studies, for e.g. Employee Relations (Kumar et al., 2020) and Financial Review (Baker et al., 2020), as topics or fields of study.

The composed data was then analysed using the computer programs Bibliometrix R package (Aria \& Cuccurullo, 2017) and VOSviwer (Van Eck et al., 2010). To answer the research question one i.e. what is general description and publication trend in JIC in term of top ranked authors, top cited articles, top publishing institutes and countries, and top ranked key words, we used Bibliometrix R package (Aria \& Cuccurullo, 2017). Similarly, to answer research question two i.e. conceptual, intellectual and social structure of the extent and impact of intellectual capital knowledge in JIC, we developed graphical mapping (bibliographic coupling, co-citation analysis, co-occurrence of keywords analysis etc.) of bibliographic information (Sinkovics, 2016) using VOSviwer (Van Eck et al., 2010).

\section{Results, findings and Discussion}

This section discusses the results and findings of the bibliometric analysis of JIC corpus's indicators retrieved from Scopus. Since its first issue was published (in 2000) to date JIC has published 737 documents which includes 659 articles, 63 review articles, 8 editorials, and 7 research notes. These 737 documents have received 29273 citations (on date of data retrieval) with a ratio of (cites/study) being 39.7 and the $h$-index of the journal is 73 . We now present our results, based on our research questions.

\subsection{Publication trends and general description of publications in JIC}

The research question one is to understand the general publication description, publication trends and citation structure of the extent and impact of intellectual capital knowledge in JIC knowledge base.

\subsubsection{General publications trend and citation structure of JIC over 20 years}

Over the last 20 years JIC publications are portrayed through figure one, which presents the annual evolution of the number of published documents in JIC. In 2000, the first year of JIC publications, it published 24 documents and within the next 6 years, the annual number of publications in JIC reached 44. From 2008 to 2014, the annual number of publications has been decreased, however this trend reversed in 2015 and gained momentum again. Generally, the number of publications in a journal should increase over a period of time due to two main reasons i.e. increased interest of scholars in a particular domain and advancement of digital information technology infrastructure that increases the ease of access, submission, and 
distribution publications (Martínez-López et al., 2018; Merigo et al., 2015). Another specific cause to the progression of publications in JIC is the increased popularity of intellectual capital as a scholarly domain. A number of academic examinations (Bontis and Fitz-enz, 2002; Chen et al., 2005) have established a positive relationship between intellectual capital and firm performance.

\section{INSERT FIGURE ONE HERE}

Next, in order to understand impact of the journal we developed the citation structure of the JIC using various citation threshold for last two decades (Table 1). It is evident from the Table 1 that the number of citations for JIC are increasing and JIC has received 29,273 citations (on the date of data retrieval). During the initial few years, JIC publications have not received significant citations as compared to recent years, wherein the number of documents cited more than 10 and 50 times (in a particular year) increased significantly. In terms of citation count, 0.27 percent of JIC publications have been cited more than 500 times, almost 7.5 percent documents received more than 100 citations, 15 percent documents have received more than 50 citation, almost 28 percent documents have received at least 20 citation, almost 31 percent documents were cited more than 5 times, and only around 7 percent documents have not received any citation. Majority of these (7 percent) documents are published in 2019 and 2020, except editorials and commentaries. The number of publications appearing in other sources citing JIC are also increasing speedily and this number crossed the threshold of 100 within the first few years of JIC and thereafter crossed the threshold of 1000 in 2019. This indicates the impact and significance of JIC on debates about intellectual capital and knowledge.

As a next step we analysed the leading trends in terms of top authors, institutes, countries and journals, citing JIC publications. Table 2 ranks the top 25 Authors, Institutes, Counties and Journals who cited JIC. Our analysis found that Bontis, N. lead the list and published 77 documents citing JIC and almost 17 authors among the list have published more than 25 documents each. McMaster University and Macquarie University lead the list of Institutions who are citing JIC. The majority of the institutions in the list are from Europe. In terms of countries, United Kingdom, Italy, United States, Spain leads the list. European countries dominate this list also followed by countries from the Asian continent. In terms of top journals, we found the phenomenon of self-citation in JIC also. Self-citation is very usual phenomenon among journals (Merigo et al., 2018). Other journals which have publications citing JIC are Journal of Knowledge Management, International Journal of Learning and Intellectual Capital, Knowledge Management Research and Practice, Management Decision, Journal of Business Research, and so on. The majority of these journals have knowledge management, information systems and similar applications as main scope. 


\subsubsection{Key authors in JIC and their Citation Structure}

This section offers a general overview of the most productive authors, their various citation index and their citation structure using various citation thresholds. This analysis reveals an author's highest achievements in terms of number of publications and citations as per the Scopus database (Merigo et al., 2018). Table 3 presents the most productive authors who have published at least five documents in JIC, excluding editorials. The list includes 27 authors, and these authors are ranked as per number of publications, in case of a tie in publication numbers, we ranked them according to their number of citations. Table 3 also presents the current affiliation of the top ranked authors.

The raking identified John Dumay of Macquarie University, Australia as most productive author. He has authored 29 documents in JIC and has received 1118 citations with $h$ index 18. Authors from Australian universities dominates the list of top publishing authors, followed by authors from Italian universities. Table 3 also presents the citation structure of the top publishing authors with respect to certain citation thresholds.

-INSERT TABLE THREE ABOUT HERE

\subsubsection{Most influential(cited) papers published in JIC}

Since its first issue, JIC has produced many impactful contributions which have made significant contributions in business and management research. Table 4 ranked 25 most influential papers published in JIC in last two decades, as per Scopus database. The top two publications in the list have received more than 500 hundred citations each. The top ranked article is authored by Bontis et al (2002) and examines the relationship between intellectual capital and business performance with 34.3 citations per year. The second ranked document (Petty and Guthrie, 2000) is a review paper which consolidates the measurement, reporting and management of intellectual capital. The majority of the documents in the list have appeared during 2000 and 2001.

A close analysis of this list reveals that a significant proportion of these publications examines the relationship between intellectual capital and firm performance. Other issues addressed by these publications covers measurement, reporting and disclosure of intellectual capital.

\subsubsection{Most cited documents in JIC}

This section discusses the publication which have received maximum citations in JIC. Table 5 present the list of the top 25 publications which have received maximum citations in JIC. The 
top ranked document is authored by Bontis (1998) and published in Management Decision. This article explores the measure and models of intellectual capital. The oldest article in terms of year of publication appeared in 1996 and newest one was published in 2016. The majority of these articles are review articles, which consolidates our knowledge on various intellectual capital topics. Another observation is that a major proportion of this list's documents are published in JIC. The remaining publications are from journals such as Management Decision, Academy of Management Journal, Academy of Management Review, Long Range Planning, European Management Journal and so on.

\section{INSERT TABLE FIVE ABOUT HERE-}

\subsubsection{Most productive Institutions, Countries and most frequent Keywords}

Table 6 ranks the most productive institutions and countries in terms of number of publications and citations received, on the topic. In addition, this table also ranks 25 most frequently used keywords. Please note that the number of publications is considered as ranking criteria and in case of a tie, citations received is considered as a ranking criterion. Macquarie University with 44 publications is the most productive institution in JIC. The list is followed by McMaster University (27 publications), The university of Sydney (17 publications), Cranfield school of management (13 publications) and University of Ferrara (13 publications).

JIC is thus established as a truly international journal, which has provided a platform to scholarly publications from across the globe. The list of top 25 countries is led by Italy with 120 publications and 5845 citations. This is followed by Australia (number of publications 109), USA (84 publications), UK (68 publications) etc. This ranking list indicates that JIC strongly attracts European and Australian scholars. However, apart from European countries many Asian countries have also appeared in top the 25 ranked list of countries.

Table 6 also presents the 25 most frequently appeared authors key words. The list includes key words such as intellectual capital, intangible asset, knowledge management, human capital, intellectual capital, financial reporting and so on.

\section{-INSERT TABLE SIX ABOUT HERE--}

\subsection{Conceptual structure of JIC Publication Corpus}

Bibliometric analysis is used extensively to develop the knowledge structure of a particular domain (Aria and Cuccurullo, 2017). Part one of research question two (2 a) of the present study is about understanding the conceptual structure (sate and evolution) of the scholarship published in JIC in the last two decades. To achieve part of this research objective, we used coword analysis and constituted strategic diagram of authors keywords used in 737 publications of JIC. Co-word analysis provides insight about various themes or concepts within a knowledge domain (Van Eck and Waltman, 2010). Key words are considered as the representative terms of the content/themes in a knowledge domain and the co-occurrence of keywords in a document indicates the linkage between the themes of the document (Zupic \& Čater, 2015). Keywords of a document are assumed to present an appropriate description of a documents' content and 
their co-occurrence reveals the pattern and evolution of a knowledge within a domain (Aparicio, et al., 2019).

For constructing the strategic diagram of JIC research, we considered 500 keywords out of a total of 1208 keywords and used a bibliometrix package to visualize a strategic diagram. A strategic diagram displays various themes which are characterized by measures such as centrality and density (Cobo et al., 2015). Centrality denotes the degree of interaction or strength of ties of a theme, with other themes and density, and is a measure of strength of internal ties within a theme (Aparicio, et al., 2019; Murgado-Armenteros et al., 2015). On the basis of degree of centrality and density, a strategic diagram displays a quadrant and represents four types of themes i.e. motor theme (upper right quadrant, high centrality and high density), peripheral theme (upper left quadrant, high density and low centrality), emerging or disappearing (lower left quadrant, with low density and low centrality) and transversal, general or basic theme (lower right quadrant, with low density and high centrality).

The strategic diagram (figure 2) presents a total 8 themes in the four quadrants. Three themes namely Intellectual Capital, Disclosure, and Intellectual Property come under the general or basic quadrant. These three themes appeared as very important themes in JIC knowledge bases. Themes in this quadrant have a high density and low centrality, and means that these themes have a high strength of internal ties and are well developed. The size of the circles substantiates that these themes are well researched, however, scholarly inquires in these themes are further warranted.

Intellectual capital theme is seen to be the largest is size and constituted of keywords such as intellectual capital, intangible asset, knowledge management, human capital, social capital, relational capital, measurement and performance etc. This theme appears as the fundamental theme in JIC research corpus and research on this theme have addressed the fundamental questions relating to the concept and measurement of intellectual capital in various contexts. The publication period for this theme is spread over entire 20 years span.

Disclosure was found to be the second largest theme, which appeared in the basic quadrant and constituted of keywords such as integrated reporting, finance reporting, intellectual capital reporting, annual reports, intellectual capital disclosure, etc. Researches under this theme addressed the issue of reporting and disclosure of intellectual capital such as disclosure of nonfinancial capital, trends in intellectual capital disclosure, human capital disclosure, competitiveness and intellectual capital disclosure etc. Similar to the previous theme, this theme's research appeared over a 20 years' span.

The third theme which appears in the basic quadrant is intellectual property and this theme includes keywords such as patents, assets valuation, resources, japan and performance management etc. This theme has addressed the research issues such as scale development and modelling of intellectual property, auditing of patents portfolios, option pricing in intellectual property, valuation of intellectual property and so on. The majority of the research on this theme is published in blocks, which were seen to be 2000-2002, 2005-2008 and 2018-2019.

Universities, as a theme, appeared mainly as a motor theme and constituted of keywords such as knowledge, research, higher education, public sector, intellectual capital management, Italy, Spain etc. This theme appeared as a motor quadrant, which means this theme has been well developed, important and central for the JIC research corpus. Research on this theme primarily 
examines issues related to intellectual capital in universities such as intellectual capital reporting in universities, future direction of IC research in universities, IC and university performance, IC management in universities, patents, research and development activities in universities etc. The majority of the publications on this theme appeared between 2013-2018.

Value, as the next theme appeared partially as a motor and partially as a peripheral theme, and this includes keywords such as balanced score card, entrepreneurship, tacit knowledge, company performance, knowledge sharing, knowledge transfer, company performance etc. Positioning of this cluster indicates that this theme is important in establishing JIC research and is also somewhat niche as this examines issues such as location of a firm in intellectual capital performance, intellectual capital and book value of productivity, intellectual capital and firm market value and value creation, etc. Most of these publications appeared between 20042014. However, this theme has contributed significantly in establishing intellectual capital as an important phenomenon for modern organizations.

Two themes namely Strategy and, Value Creation appeared under the peripheral or niche theme. The size of these themes denotes the quantity of publications and it indicates that these are very focused themes and includes publications on value creation through intellectual capital and strategic focus on intellectual capital. The theme Strategy has publications such as firm strategy and cybersecurity from knowledge perspective, and intellectual capital for supporting firm strategy, intellectual capital and overall strategy etc. The publication period of these documents is spread over the last two decades. The theme Value creation has publications that includes topics or issues such as intellectual capital and big data, intellectual liabilities, contribution of intellectual capital in value creation, value driver for intellectual capital in university, benefits and cost of intellectual capital in small firm etc. The publication period of this area of research suggests that this is an evolving theme in JIC, as the majority of these publications appeared in the last few years.

The lower left quadrant of the strategic diagram (Figure 2) includes a key theme namely Organizational Learning. This indicates this could be either an emerging or disappearing theme within the JIC research corpus. Our analysis however suggests that this is a disappearing theme and publications having keywords of this theme were published during initial years of the JIC and very few were published around 2011 and 2012. These publications were mainly on learning organization, diffusion of tacit knowledge in organizations, performance measurement for human capital building etc.

Conclusively, the above section thus presents the conceptual structure of the JIC research and our analysis found that JIC research has been mainly structured under 7 key themes

\subsection{Intellectual structure of the JIC research}

The second part of our research question two $(2 \mathrm{~b})$ of the study is about developing and understanding the intellectual structure of the extent and impact of the JIC knowledge base. Intellectual structure can be understood as an "organised map of salient features of a knowledge base and it reveals the disciplinary composition and tradition of research in a knowledge domain" (Shafique, 2013, p 2). In order to constitute the intellectual structure of JIC knowledge base, this study employs bibliometric and network methods i.e. historiography which is based on a combination of direct citation of pioneer/milestone research work; co-citation analysis of 
authors and journals cited; and bibliographical coupling of authors (Aria and Cuccurullo, 2017).

\subsubsection{Historiography of JIC Corpus}

Encyclopaedia Britannica defines historiography as a writing of history based on critical examination of selected knowledge sources. In other words, a historiographic map reveals how ideas travel through time from one source of knowledge to another source of knowledge i.e. publications in current section (see work by Sarnecky, 1990 in the context of nursing as a topic of research). We have thus developed a historiographic map of the most influential publications of JIC, in essence to understand and visualize the progression of research ideas in JIC chronologically.

Figure 3 shows the historiography map of the top 50 most influential publications in/of JIC. Our examination of the map shows two distinct streams of research. One stream of research primarily focuses on the relationship between intellectual capital and firm performance and/or its competitive advantage (Bontis et al., 2000; Bontis and Fitz-enz, 2002; Clarke et al., 2011; Chen Goh, 2005; Pew Tan et al., 2007; Joshi et al., 2013; Dženopoljac et al., 2016). Further to such empirical examinations of the said relationship, we see review based research work also undertaken, to consolidate scholarships within this stream (Inkinen, 2015). One important subtheme of research under this stream is the measuring of intellectual capital (Nazari and Herremans, 2007; Keong Choong, 2008).

The second research stream in JIC research corpus primarily focuses on the reporting of intellectual capital (April et al., 2003; Dumay, 2009). We observed a topicality movement in this stream of research i.e. reporting of a disclosure of intellectual capital (Abeysekera, 2006; Dumay, 2016). Value creation and value addition were other key and important subthemes emerging within this stream of research (Bismuth and Tojo, 2008; Marr et al., 2004).

Figure 3 also suggests that there is a subset of knowledge sources (Abdolmohammadi, 2005; Bounfour, 2003) that links these two main streams of research. within the JIC corpus. Conclusively, the historiographic map shows that there are two main streams of research with one subtheme in each stream. Though these two streams have grown in parallel, however there has been a greater focus of the second stream, as compared to the first, as it has received more scholarly attention. Another observation is that around 2004-06 few publications provided linkages between these two influential streams of research in JIC publications

\section{-INSERT FIGURE 3 ABOUT HERE}

\subsubsection{Co-citation analysis of sources and documents}

We further developed a co-citation network to have an in-depth understanding of the evolution of knowledge base in JIC. As is understood from the literature, co-citation occurs when for e.g. document A and document B are cited together in a document C (Small, 1973). Co-citation usually considers references of primary documents, and thus it is implemented for cited documents and journals (Martínez-López et al., 2018). Co-citation network analysis is thus 
usually considered as a means to understand the historical evolution of a particular knowledge base.

As a first step, we developed a co-citation network of cited journals in JIC. Out the 10,646 sources, 203 met the initial criteria of a minimum 20 citations. Among these 203 sources, we considered the top 100 sources, with a maximum link strength. The co-citation analysis of the top 100 linked sources cited in JIC yielded a network of three clusters (see Figure 4). This network has 4,745 links with a total link strength of 30,5928. Cluster one (grey) is the largest cluster and it has 55 sources in it. Few of these include studies from the Academy of Management Journal, Journal of Knowledge Management, Strategic Management Journal, Journal of Management, Management Decision, Journal of Management Studies, Organization Science, and so on. We named this cluster as general management and knowledge management cluster. The second largest cluster in the network is then positioned just opposite of cluster one. This cluster has 32 sources, that include for e.g. the Journal of intellectual Capital, Journal of Accounting Research, European Accounting Review, Accounting and Business Research, The Accounting Review- to name a few. We named this cluster accounting review cluster. It is evident from the figure that this cluster is based in JIC and hence depicts the high degree of conceptual similarity of intellectual capital with the accounting domain. The third cluster (dark grey colour) has 13 sources, and here, most of these sources are books, and hence we named this cluster as book cluster.

-INSERT FIGURE 4 ABOUT HERE

Our next step then included the construction of a co-citation network of cited documents. Out of 31,298 cited documents 558 met the initial criteria of minimum 5 citations and on the basis of a maximum link strength among these documents, the top 100 documents were considered for network development. The co-citation network of cited documents (see Figure 5) has yielded three clusters with 3,719 links with a total link strength of 11,260. We named this cluster after the main theme of the documents within the clusters. Cluster one, (grey colour nodes) has 39 items and include a few main issues that are addressed in this cluster, which are measures and models of intellectual capital, intellectual capital and firm performance etc. Here, cluster one was named as intellectual capital and performance cluster. This cluster is mainly based on Bontis' work. Cluster two (white colour nodes) constituted of 31 documents and the main theme of examination in this cluster was the reporting and disclosure of intellectual capital. Cluster two is based in the work of Bozzolan and colleagues. Cluster three (dark grey colour) has 30 documents and this cluster was mainly about consolidating the intellectual capital research. This cluster is based in Guthrie and Dumay. 
Our next step involved developing a bibliographic coupling network. Bibliographic coupling is another extensively employed approach, which aids in visualizing knowledge networks within a domain (Zhao and Strotmann, 2008; Bamel et al., 2020). The difference between cocitation network and bibliographic coupling network is that co-citation network considers secondary documents to understand the historical focus and evolution of a field, whereas bibliographic coupling is future oriented and it considers primary documents for identifying the emergent topics and future directions of a field (Vogel, 2012). Two units A and B (paper, author, institutes etc.) are said to be bibliographic coupled if they both cite a unit C. In other words, two bibliographically coupled units would have a degree of similarity in their references (Van Eck and Waltman, 2014). We created two bibliographic networks using authors (see figure 6) and documents (see figure 7), as unit of analysis. These networks are detailed below.

For constructing authors' bibliographic network, out of 1,196 authors, the top 100 authors with a maximum link strength were considered. This yielded a network with four clusters (Figure 6) having 4,950 links and 187,818 total link strength.

Cluster one (red colour nodes situated on the hand left side of the network) is the largest cluster of the network and includes 53 authors. This cluster is based in Bontis, apart from a few other influential authors in this cluster, namely Roos, G., Bounfour, A., Durst, S., Cricelli, L., and so on. Since the early years of JIC-to date the main focus of this cluster is on intellectual capital and firm performance (Bontis e al., 2000; Agostini et al., 2017). However, the indicators of firm performance are now moving from the traditional measures of performance to novice indicators such as innovation, competitive advantage, value creation, wealth creation etc. In terms of emerging focus, value creation, innovation, concept of value and integration of strategic perspective, within the intellectual research domain, and hence these are now the newly emerging research areas within JIC (Bounfour et al. 2018; Pedro et al., 2019).

Cluster two (white colour nodes) are the second largest cluster in the network and this cluster is based in Chiucchi, M.S., Massaro, M., Lombardi, R., Johanson, U., Giuliani, M., Bukh, P.N., Abeysekera, I. and so on. The main research focus of this cluster remains on reporting and disclosure of intellectual capital (Davey et al., 2011; Dumay, 2019), however it is found that this theme is moving towards a mandatory framework for reporting and disclosure of intellectual capital.

Cluster three (blue colour nodes on the bottom of the network) constitutes 10 scholars. This cluster has a niche focus on creation and measurement of intellectual capital (O'Donnell, 2004; Grimaldi et al., 2018). This cluster also explores the role of certain HR practices in creation of intellectual capital and interestingly has an emphasis on university as a unit of analysis.

The smallest cluster (yellow colour nodes, situated on the upper side of the network) constitutes of 5 scholars, namely Bianchi, Martini S., Corvino, A., Doni, F. and Rigolini, A. and Anifowose, M. This cluster appeared as a niche cluster, though it is emerging and primarily addresses the issue of relational capital with respect to its reporting and firm performance (Corvino et al., 2019). 
Our next steps included developing a bibliographic coupling network of documents published in JIC. The top 100 articles having maximum link strength with at least 20 citations from a total of 737 publications were considered for this network. The bibliographic coupling network for the documents generated a three-cluster network (see Figure 7) with 4,928 links with a total link strength of 33,195.

Cluster one (red colour nodes, situated on the right-hand side of network) is the largest among the three clusters and constitutes 46 documents. This cluster is represented by Roos (2017) and it integrates economic complexity theory, knowledge management with national prosperity, through the lenses of intellectual capital. Another seminal work situated in this cluster is that of Martín-de castro G. (2019), which offers future directions of intellectual capital research. Asiaei et al., (2018; 2020) work extends the scope of intellectual capital domain to human resource practices such as performance management. Another identified offshoot of intellectual capital research is the role of intrapreneurship (Asiaei et al., 2020). Diversification, as a topic of research is also an extension in terms of a contextual focus i.e. geography (from developed economies to developing) and industry (from financial, non-profit, to heath care institutions). Contextual diversification of a research field is usually warranted to establish the legitimacy of a domain. Our analysis, also depicts a few other emerging areas, such as social capital, innovation and informational and communication technology (ICT), within this cluster.

Cluster two (green colour nodes positioned on the left-hand side of the network) is the second largest cluster in the network and constitutes 38 primary publications. This cluster is represented by Cabrita (2017), and the main focus of this field of research is on reporting and disclosure of intellectual capital. An emerging trend in this cluster is social media (Pisano et al., 2017), and big data (Secondo, 2017). The third cluster (blue colour nodes located beneath cluster one) is the smallest cluster in the network and is constitutes 16 papers. This cluster is represented by Pedro et al., (2018); Dzenopoljac et al., (2017) and the focus of this cluster is limited to the relationship between intellectual capital and firm performance (Singh, 2020). This theme of research is continuously gaining maturity, specifically in terms of contextualization and indicators of performance.

Conclusively, the bibliographic coupling network suggests a few areas which are perpetual and continuing in nature, and these include intellectual capital and firm performance linkages. These are however also evolving in terms of indicators of performance. Similarly, reporting and disclosure remains the most researched field in JIC, for now. A few other emerging areas of research in JIC are innovation, big data, social media, integration of various theoretical models such HR practices, certain phenomenon of physics, etc., within intellectual capital research.

\subsection{Social structure of JIC publications}

To address the next part of research question two (2c), of the study, we employed collaboration analysis of authors, that appeared in JIC publications. Collaboration analysis is a tool to understand the social structure of a research domain (Aria and Cuccurullo, 2017). We considered all 1,196 authors and based our analysis on the maximum collaboration strength of a network of 137 constituent authors (Figure 8). This network has 13 clusters, and we named these cluster after the name of authors who were central to the cluster. 
Cluster one is the largest cluster (21 authors) and is central to the social network. This cluster is represented by Dumay, J., and it has a few sub-clusters. Sub-cluster 1 is represented by Farneti, F., Gasonato, F., Valentinetti, D.; similarly, sub-cluster 2 is represented by Garanin, T., Berezinets, I. and Andreeva, T; and sub-cluster 3 is represented by authors namely Lombardi and R., Cuozzo, B. It is thus evident from the social network that cluster one is very heterogeneous.

Cluster two is the second largest cluster and has 19 authors, who are grouped in this cluster. The main authors in this cluster are Bukh, P.N., Mouritsen, J., Nielsen, C. Lee, A. and so on. This cluster is also very heterogeneous and has many sub-clusters. Cluster three is the third largest group of authors (14 authors) and is represented by Roos, J., Pike, S. and Fletcher, A.

Cluster four includes 13 authors and is represented by Guthrie, J. and a few other prominent authors, namely Petty, R. and Caddy, I. Cluster five also includes 13 authors and is represented by Johanson, U. and Skoog, M., Holland, J. and so on. Cluster six, again also includes 13 authors and is represented by Secundo, G.

Cluster seven, has nine authors and is represented by Marr, B. and Chatzkel, J. cluster eight, is represented by Manes Rossi, F. and Nicolo, G. and has eight authors in total. Cluster nine has six authors and is represented by Abhayawansa, S.A. This cluster is positioned near the Guthrie cluster, depicting a proximity. Cluster ten also has 6 authors and this is represented by Massaro, M. and Bagnoli, C., and here too, this cluster has a proximity with the Dumay cluster.

Cluster eleven, twelve and thirteen are comprised of 5 authors each. Cluster eleven is represented by Schiuma, G. and Carlucci, D. C., and this cluster has a proximity to the Marr and Secundo cluster. Cluster twelve is represented by Chiucchi, M.S. and Giuliani, M. and has proximity to the Bukh cluster. Clauter thirteen is represented by Massingham and is connected with the Dumay cluster.

Conclusively, the social structure/network (Figure 8) depicts that there are various collaboration networks in JIC scholarship, and that JIC has been attracted by scholars from diverse domains.

\section{Implications}

This study contributes by offering a reflection on the extent and impact of intellectual capital knowledge in JIC over the past 20 years, utilizing a quantitative and structured literature review. Our reflective analysis offers an opportunity to look back and aids in the future progression of a knowledge field, such as intellectual capital. More specifically, we answered two key research questions: first, we identified the general research trends within JIC i.e. the most productive authors, institutes and countries, most influential work, citation structure of JIC publications, etc.; question two ( $\mathrm{a}, \mathrm{b}$ and $\mathrm{c}$ ) was about the extent and impact of intellectual capital knowledge in JIC by presenting the conceptual, intellectual and social structure of JIC publications. To answer these research questions, our analysis utilized the bibliometric indicators of JIC publications published during a twenty-year period i.e. 2000-2020.

Our data was analysed in two stages. In stage one we employed Bibliometrix R (Aria and Cuccurullo, 2017) to identify general trends and provide a description to the JIC research base. In stage two, we developed a knowledge structure by constructing strategic diagram using coword analysis (Bibliometrix R by Aria and Cuccurullo, 2017), intellectual structure by 
developing historiography map (employing Bibliometrix R by Aria and Cuccurullo, 2017), and co-citation and bibliographic coupling networks, and lastly social structure of the JIC research (employing VOSviwer by van Eck and Waltman, 2009).

Our key findings indicate that the impact of JIC is growing, both in terms the size of annual publications and the impact of these publication on the relevant research field. JIC has been cited almost 29,273 times and more than 7 percent of journal publications have received above 100 citations. The majority of JIC documents i.e. 93 percent have received at least one citation. For a young journal, with a very specific focus, this citation pattern depicts the stature of the journal. Further, JIC has been cited in other key journals, namely Journal of Knowledge Management, Management Decision, Journal of Cleaner Production, Expert Systems with Applications and so on, which also substantiates the standing of JIC among peer journal titles. In terms of geographical locations, Italy dominates the list, followed by Australia and USA. The most productive Institute is represented by Macquarie University, followed by McMaster University. The top rank in term of most influential paper of JIC is Bontis et al (2002) followed by Petty and Guthrie, (2000) and Bontis et al. (2002), whose work proposed and examined the intellectual capital-firm performance whereas Petty and Guthrie (2000) talk about reporting of intellectual capital. Interestingly, our further analysis (historiography map) reveals that these two pieces played a role in establishing the two important research streams in JIC. That said, our analysis is also suggesting newer areas of relevant research that are evolving. Analysis on the general description of JIC provides an understanding about the research patterns and leading trends within JIC. This will aid in helping the editorial board members of JIC and scholars' community to focus on topics, that are both core to them and also on less examined topical areas, that needs increased attention.

We also contribute through the understanding of the conceptual structure of the JIC research base, through a strategic diagram, which was constructed using co-word analysis of authors keyword. Our analysis suggests that almost all of JIC research can be structured into eight themes i.e. three general or basic themes (Intellectual Capital, Disclosure, and Intellectual Property), one motor theme (Universities), one partial motor and partial peripheral theme (Value Added), two peripheral themes (Strategy and, Value Creation), and one disappearing theme (Organizational Learning). These eight sub-concepts of the JIC research base offers an understanding of the central and well-developed topics, as well as the underdeveloped and emerging topics. This understanding thus provides direction for the potential extension of JIC research base. For example, research on Strategy and Value Creation themes has a potential to be extended in future.

Our next contribution was by aiding in understanding the disciplinary composition of the salient features of JIC knowledge base, through the intellectual structure of JIC publications. Here, three type of maps/network were constituted. First, we developed a Historiography map of the top 50 influential research papers of JIC. Our analysis reveals, that since its inception, JIC research included two major research themes i.e. intellectual capital \& performance and, reporting \& disclosure of intellectual capital. This analysis helps in understanding how the knowledge base within JIC has moved over time. For example, the research theme reporting has moved from voluntary reporting to structural framework of disclosure of intellectual capital.

Second, we employed a co-citation analysis of secondary documents to understand the intellectual foundation of JIC research base. We developed two co-citation networks i.e. sources and documents. Co-citation network of sources revealed three sets of knowledge bases i.e. accounting review, general \& knowledge management, and books. JIC research was thus 
earlier primarily rooted within the accounting research domain, however since then, it is being evolving by embracing newer forms of intellectual capital research, as it is still a new field of inquiry. The co-citation network of cited documents, in this paper, has identified two important research themes (through the historiography map). The historiography map provides an understanding about the evolution and historical progression of JIC research base. In the last two decades, intellectual capital research base is continuously expanding and is seeing an upgradation in terms of theories and application. Intellectual capital is thus adding value to firms as it helps them in achieving competitive advantage.

Third, to understand the future (emerging themes) of JIC, we developed a bibliographic coupling network of the most productive authors and most influential documents published in JIC. This analysis reveals possible future research themes for JIC, of which some key areas include- the disclosure practices for intellectual capital, role of intellectual capital in innovation, big data in intellectual capital, and integration of various theoretical framework in intellectual capital research. These findings would help in extending present and future intellectual capital research, in JIC, in a meaningful way. Fourth, we presented the current state of collaboration among scholars published/publishing in JIC, by developing a co-authorship network of scholars. The co-authorship network we developed, reveals the existence of various publishing teams within JIC. This may help authors working in this area to observe past collaborations, and help develop newer collaboration with others.

Finally, our study provides a guiding framework for organizations in designing policies and interventions for promoting the intellectual capital. Our research identifies important themes within the intellectual capital knowledge field as it establishes its relevance with firm performance- the bottom line for all managers. Thus, the knowledge detailed in this review is of great utility for executives and practitioners.

\section{Conclusion \& limitation}

In conclusion, this paper offers a holistic view of the JIC knowledge base. Through this contribution, the information on various trends, themes, and research streams in JIC would be easily available for researchers. However, this study is also not free from certain limitations. We only analysed bibliometric information of papers and not the entire content. Although, it is assumed that keywords that were used usually represents the main content of the documents, there could however include certain limitations. Thus, an integration of this type of literature review with traditional review would enhance the overall capital of such studies. That said, we believe that this contribution aids intellectual capital scholars focus on impactful future research. 


\section{References}

Abdolmohammadi, M. (2005), "Intellectual capital disclosure and market capitalization", Journal of Intellectual Capital, Vol. 6 No. 3, pp. 397-416.

Abeysekera, I. (2006), “The project of intellectual capital disclosure: researching the research", Journal of Intellectual Capital, Vol. 7 No. 1, pp. 61-77.

Agostini, L., Nosella, A. and Filippini, R. (2017), "Does intellectual capital allow improving innovation performance? A quantitative analysis in the SME context," Journal of Intellectual Capital, Vol. 18 No. 2, pp. 400-418.

Aparicio, G., Iturralde, T. and Maseda, A. (2019), "Conceptual structure and perspectives on Entrepreneurship education research: A bibliometric review", European Research on Management and Business Economics, Vol. 25 No.3, pp.105-113.

April, K., Bosma, P. and Deglon, D. (2003), "IC measurement and reporting: establishing a practice in SA mining”, Journal of Intellectual Capital, Vol. 4 No. 2, pp. 165-180.

Aria, M., and Cuccurullo, C. (2017), "bibliometrix: An R-tool for comprehensive science mapping analysis," Journal of Informetrics, Vol. 11 No. 4, pp. 959-975.

Asiaei, K., Barani, O., Bontis, N. and Arabahmadi, M. (2020), "Unpacking the black box" Journal of Intellectual Capital, Vol. ahead-of-print No. ahead-of-print.

Asiaei, K., Jusoh, R. and Bontis, N. (2018), "Intellectual capital and performance measurement systems in Iran”, Journal of Intellectual Capital, Vol. 19 No. 2, pp. 294-320.

Baer, W., Bounfour, A. and Housel, T.J. (2018), "An econophysics non-monetized theory of value: The case of micro-finance in Sub-Saharan Africa", Journal of Intellectual Capital, Vol. 19 No. 3, pp. 519-535.

Baker, H. K., Kumar, S. and Pattnaik, D. (2020), "Fifty years of The Financial Review: A bibliometric overview", Financial Review, Vol. 55 No. 1, pp. to be allotted.

Bamel, U. K., Pandey, R. and Gupta, A. (2020), "Safety climate: systematic literature network analysis of 38 years (1980-2018) of research", Accident Analysis \& Prevention, Vol.135, 105387.

Bismuth, A. and Tojo, Y. (2008), "Creating value from intellectual assets", Journal of Intellectual Capital, Vol. 9 No. 2, pp. 228-245.

Bongiovanni, I., Renaud, K. and Cairns, G. (2020), "Securing intellectual capital: an exploratory study in Australian universities", Journal of Intellectual Capital, Vol. 21 No. 3, pp. 481-505.

Bontis, N. (1998), "Intellectual capital: an exploratory study that develops measures and models," Management decision, Vol. 36 No. 2, pp. 63-76.

Bontis, N. (2001), “Assessing knowledge assets: a review of the models used to measure intellectual capital", International Journal of Management Reviews, Vol. 3 No.1, pp. 41-60. 
Bontis, N. and Fitz-enz, J. (2002), "Intellectual capital ROI: a causal map of human capital antecedents and consequents", Journal of Intellectual Capital, Vol. 3 No. 3, pp. 223-247.

Bontis, N., Chua Chong Keow, W. and Richardson, S. (2000), "Intellectual capital and business performance in Malaysian industries", Journal of Intellectual Capital, Vol. 1 No. 1, pp. 85100.

Bounfour, A. (2003), "The IC-dVAL approach”, Journal of Intellectual Capital, Vol. 4 No. 3, pp. 396-413.

Budhwar, P., Pereira, V., Mellahi, K. and Singh, S. K. (2019), "The state of HRM in the Middle East: Challenges and future research agenda", Asia Pacific Journal of Management, Vol. 36 No.4, pp. 905-933.

Cabrita, M. D. R. M. F., da Silva, M. D. L. R., Rodrigues, A. M. G. and Dueñas, M. D. P. M. (2017), "Competitiveness and disclosure of intellectual capital: an empirical research in Portuguese banks," Journal of Intellectual Capital, Vol. 18 No. 3, pp. 486-505.

Chen Goh, P. (2005), "Intellectual capital performance of commercial banks in Malaysia", Journal of Intellectual Capital, Vol. 6 No. 3, pp. 385-396.

Chen, M., Cheng, S. and Hwang, Y. (2005), “An empirical investigation of the relationship between intellectual capital and firms' market value and financial performance", Journal of Intellectual Capital, Vol. 6 No. 2, pp. 159-176.

Christofi, M., Vrontis, D. and Cadogan, J. W. (2019) "Micro-foundational ambidexterity and multinational enterprises: A systematic review and a conceptual framework", International Business Review, Vol. 101625.

Clarke, M., Seng, D. and Whiting, R. (2011), "Intellectual capital and firm performance in Australia", Journal of Intellectual Capital, Vol. 12 No. 4, pp. 505-530.

Cobo, M. J., Martínez, M. Á., Gutiérrez-Salcedo, M., Fujita, H. and Herrera-Viedma, E. (2015), "25 years at Knowledge-based systems: A bibliometric analysis", Knowledge-based systems, Vol. 80, pp. 3-13.

Corvino, A., Caputo, F., Pironti, M., Doni, F. and Martini, S. B. (2019), "The moderating effect of firm size on relational capital and firm performance", Journal of Intellectual Capital, Vol. 20 No. 4, pp. 510-532.

De Mauro, A., Greco, M., Grimaldi, M., \& Ritala, P. (2018), "Human resources for Big Data professions: A systematic classification of job roles and required skill sets", Information Processing \& Management, Vol. 54 No.5, pp. 807-817.

de Pablos, P. O. and Edvinsson, L. (2020), Intellectual Capital in the Digital Economy, Routledge, Abingdon, Oxon.

Dumay, J. (2009), "Intellectual capital measurement: a critical approach", Journal of Intellectual Capital, Vol. 10 No. 2, pp. 190-210.

Dumay, J. (2016), "A critical reflection on the future of intellectual capital: from reporting to disclosure", Journal of Intellectual Capital, Vol. 17 No. 1, pp. 168-184. 
Dumay, J. and Guthrie, J. (2017), "Involuntary disclosure of intellectual capital: is it relevant?”, Journal of Intellectual Capital, Vol. 18 No. 1, pp. 29-44.

Dženopoljac, V., Janoševic, S. and Bontis, N. (2016), "Intellectual capital and financial performance in the Serbian ICT industry”, Journal of Intellectual Capital, Vol. 17 No. 2, pp. 373-396.

Dzenopoljac, V., Yaacoub, C., Elkanj, N. and Bontis, N. (2017), "Impact of intellectual capital on corporate performance: evidence from the Arab regio", Journal of Intellectual Capital, Vol. 18 No. 4, pp. 884-903.

Garfield, E. (1964), “Citation indexes for science,” Science, Vol. 122 No. 3159, pp. 108-111.

Guthrie, J. and Petty, R. (2000), "Intellectual capital: Australian annual reporting practices", Journal of Intellectual Capital, Vol. 1 No. 3, pp. 241-251.

Guzmán, A., Pedro, M. A. R. I. and Wilson, C. (2018), U.S. Patent Application No. 29/606,384.

Inkinen, H. (2015), "Review of empirical research on intellectual capital and firm performance", Journal of Intellectual Capital, Vol. 16 No. 3, pp. 518-565.

Jardon, C. and Susana Martos, M. (2012), "Intellectual capital as competitive advantage in emerging clusters in Latin America", Journal of Intellectual Capital, Vol. 13 No. 4, pp. 462481.

Joshi, M., Cahill, D., Sidhu, J. and Kansal, M. (2013), "Intellectual capital and financial performance: an evaluation of the Australian financial sector", Journal of Intellectual Capital, Vol. 14 No. 2, pp. 264-285

Keong Choong, K. (2008), "Intellectual capital: definitions, categorization and reporting models", Journal of Intellectual Capital, Vol. 9 No. 4, pp. 609-638.

Kim, H.L., Hovav, A. and Han, J. (2010), "Protecting intellectual property from insider threats: A management information security intelligence perspective", Journal of Intellectual Capital, Vol. 21 No. 2, pp. 181-202.

Marr, B., Schiuma, G. and Neely, A. (2004), "The dynamics of value creation: mapping your intellectual performance drivers", Journal of Intellectual Capital, Vol. 5 No. 2, pp. 312-325.

Martínez-López, F. J., Merigó, J. M., Valenzuela-Fernández, L. and Nicolás, C. (2018), "Fifty years of the European Journal of Marketing: a bibliometric analysis", European Journal of Marketing, Vol. 52 No. 1/2, pp. 439-468.

Merigó, J. M., Mas-Tur, A., Roig-Tierno, N. and Ribeiro-Soriano, D. (2015), “A bibliometric overview of the Journal of Business Research between 1973 and 2014”, Journal of Business Research, Vol. 68 No.12, pp. 2645-2653.

Merigo, J.M., Gil-Lafuente, A.M. and Yager, R.R. (2015b), “An overview of fuzzy research with bibliometric indicators", Applied Soft Computing, Vol. 27, pp. 420-433.

Meyer, R. and Winer, R.S. (2014), "Introduction to the JMR 50 anniversary special section", Journal of Marketing Research, Vol. 51 No. 1, pp. 83-83. 
Murgado-Armenteros, E. M., Gutiérrez-Salcedo, M., Torres-Ruiz, F. J. and Cobo, M. J. (2015), "Analysing the conceptual evolution of qualitative marketing research through science mapping analysis", Scientometrics, Vol.102 No.1, pp. 519-557.

Nazari, J. and Herremans, I. (2007), "Extended VAIC model: measuring intellectual capital components", Journal of Intellectual Capital, Vol. 8 No. 4, pp. 595-609.

O'Donnell, R. (2014), Analysis of boolean functions, Cambridge University Press.

Oliveira, M., Curado, C., Balle, A.R. and Kianto, A. (2020), "Knowledge sharing, intellectual capital and organizational results in SMES: are they related?", Journal of Intellectual Capital, Vol. ahead-of-print No. ahead-of-print.

Pereira, V., Munjal, S. and Ishizaka, A. (2019), “Outsourcing and Offshoring Decision Making and its Implications for Businesses- A Synthesis of Research Pursuing Five Pertinent Questions," Journal of Business Research, Volume 103, pp. 348-355.

Pereira, V., Vrontis, D., Christofi, M., and Temouri, Y. (2019), “Analysing Three Decades of Emerging Market Research: Future Research Directions", British Journal of Management, Vol. 00, pp. 1-12.

Petty, R. and Guthrie, J. (2000), “Intellectual capital literature review,” Journal of Intellectual Capital, Vol. 1 No. 2, pp. 155-176.

Pew Tan, H., Plowman, D. and Hancock, P. (2007), "Intellectual capital and financial returns of companies", Journal of Intellectual Capital, Vol. 8 No. 1, pp. 76-95.

Popkova, E.G. and Sergi, B.S. (2020), "Human capital and AI in industry 4.0. Convergence and divergence in social entrepreneurship in Russia", Journal of Intellectual Capital, Vol. 21 No. 4 , pp. 565-581.

Pritchard, A. (1969), "Statistical bibliography or bibliometrics", Journal of documentation, Vol. 25 No.4, pp. 348-349.

Roos, G. (2017), "Knowledge management, intellectual capital, structural holes, economic complexity and national prosperity", Journal of Intellectual Capital, Vol. 18 No. 4, pp. 745770 .

Sarnecky, M. T. (1990), "Historiography: a legitimate research methodology for nursing", Advances in nursing science, Vol. 12 No.4, pp.1-10.

Shafique, M. (2013), "Thinking inside the box? Intellectual structure of the knowledge base of innovation research (1988 -2008)", Strategic Management Journal, Vol. 34 No.1, pp. 62-93.

Sinkovics N. (2016), "Enhancing the foundations for theorising through bibliometric mapping”, International Marketing Review, Vol. 33 No. 3, No. 327-350.

Small, H. (1973), "Co-citation in the scientific literature: A new measure of the relationship between two documents", Journal of the American Society for information Science, Vol. 24 No.4, pp. 265-269.

Van Eck, N. J. and Waltman, L. (2014), "Visualizing bibliometric networks", (eds) Measuring scholarly impact, Springer, Cham, pp. 285-320. 
Van Eck, N.J. and Waltman, L. (2010), "Software survey: VOSviewer, a computer program for bibliometric mapping”, Scientometrics, Vol. 84 No. 2, pp. 523-538.

Van Fleet, D., Ray, D.F., Bedeian, A.G., Downey, H.K., Hunt, J.G., Griffin, R.W., Dalton, D., Vecchio, R.P., Kacmar, K.M. and Feldman, D.C. (2006), "The Journal of Management's first 30 years", Journal of Management, Vol. 32 No. 4, pp. 477-506.

Vogel, R. (2012), "The visible colleges of management and organization studies: A bibliometric analysis of academic journals", Organization Studies, Vol. 33 No.8, pp.10151043.

Vogel, R. (2012), "The visible colleges of management and organization studies: A bibliometric analysis of academic journals", Organization Studies, Vol. 33 No. 8, pp. 10151043.

Vrontis, D. and Christofi, M. (2019), "R\&D internationalization and innovation: A systematic review, integrative framework and future research directions", Journal of Business Research, in press.

Zhao, D. and Strotmann, A. (2008), "Evolution of research activities and intellectual influences in information science 1996-2005: Introducing author bibliographic-coupling analysis", Journal of the American Society for Information Science and Technology, Vol. 59 No.13, pp. 2070-2086.

Zupic, I. and Čater, T. (2015), "Bibliometric methods in management and organization," Organizational Research Methods, Vol. 18 No. 3, pp. 429-472. 
Table 1. Citation Trends of JIC from 2000 to 2020

\begin{tabular}{|c|c|c|c|c|c|c|c|c|c|}
\hline Year & NP & Citation & $\geq \mathbf{5 0}$ & $\geq 10$ & $\geq 1$ & $\begin{array}{l}\text { Mean } \\
\text { TC per } \\
\text { Art }\end{array}$ & $\begin{array}{l}\text { Mean } \\
\text { TC per } \\
\text { Year }\end{array}$ & $\begin{array}{c}\text { Citable } \\
\text { Years }\end{array}$ & $\begin{array}{l}\text { articles in other } \\
\text { sources citing } \\
\text { JIC }\end{array}$ \\
\hline 2000 & 24 & 3 & 0 & 0 & 2 & 132.66 & 6.63 & 20 & 3 \\
\hline 2001 & 30 & 50 & 0 & 1 & 11 & 64.36 & 3.38 & 19 & 25 \\
\hline 2002 & 26 & 51 & 0 & 0 & 30 & 72.88 & 4.04 & 18 & 31 \\
\hline 2003 & 35 & 153 & 0 & 3 & 60 & 71.42 & 4.20 & 17 & 59 \\
\hline 2004 & 38 & 297 & 0 & 5 & 114 & 85.07 & 5.31 & 16 & 116 \\
\hline 2005 & 37 & 395 & 0 & 5 & 104 & 60.62 & 4.04 & 15 & 131 \\
\hline 2006 & 44 & 425 & 0 & 6 & 134 & 33.15 & 2.36 & 14 & 166 \\
\hline 2007 & 44 & 839 & 0 & 19 & 182 & 40.43 & 3.11 & 13 & 243 \\
\hline 2008 & 42 & 916 & 0 & 25 & 195 & 34.11 & 2.84 & 12 & 261 \\
\hline 2009 & 37 & 1101 & 0 & 25 & 251 & 35.10 & 3.19 & 11 & 281 \\
\hline 2010 & 30 & 1452 & 1 & 36 & 288 & 46.26 & 4.62 & 10 & 320 \\
\hline 2011 & 29 & 1422 & 0 & 33 & 300 & 44.34 & 4.92 & 9 & 401 \\
\hline 2012 & 30 & 1624 & 0 & 50 & 347 & 32.76 & 4.09 & 8 & 373 \\
\hline 2013 & 36 & 2061 & 1 & 49 & 322 & 34.638 & 4.94 & 7 & 475 \\
\hline 2014 & 31 & 2268 & 1 & 56 & 359 & 23.32 & 3.88 & 6 & 482 \\
\hline 2015 & 36 & 2549 & 2 & 63 & 366 & 25.66 & 5.13 & 5 & 554 \\
\hline 2016 & 36 & 2370 & 1 & 64 & 371 & 17.138 & 4.28 & 4 & 618 \\
\hline 2017 & 44 & 2928 & 4 & 80 & 401 & 15.75 & 5.25 & 3 & 703 \\
\hline 2018 & 46 & 3489 & 4 & 102 & 429 & 8.30 & 4.15 & 2 & 782 \\
\hline 2019 & 49 & 3848 & 5 & 116 & 434 & 1.51 & 1.51 & 1 & 1073 \\
\hline 2020 & 13 & 1032 & 0 & 16 & 361 & --- & ---- & 0 & 311 \\
\hline Total & 737 & 29273 & 19 & 754 & 5061 & & & & 7408 \\
\hline
\end{tabular}

Source: Scopus databases accessed in 12.04.2020, NP: number of publications; $\geq 50, \geq 10, \geq$ : number of papers with at least 50,10 and 1 citations respectively; 
Table 2. Top Authors, Institutions, Countries and Journals citing JIC articles

\begin{tabular}{|c|c|c|c|c|c|c|c|}
\hline $\mathbf{R}$ & $\begin{array}{l}\text { Author } \\
\text { Name }\end{array}$ & $\begin{array}{l}T \\
P\end{array}$ & Institutes & TP & Country & $\begin{array}{l}T \\
P\end{array}$ & Journal \\
\hline 1 & Bontis, N. & $\begin{array}{l}7 \\
7\end{array}$ & $\begin{array}{l}\text { McMaster } \\
\text { University }\end{array}$ & $\begin{array}{l}19 \\
2\end{array}$ & $\begin{array}{l}\text { United } \\
\text { Kingdom }\end{array}$ & $\begin{array}{l}9 \\
7 \\
2\end{array}$ & Journal of Intellectual Capital \\
\hline 2 & Dumay, J. & $\begin{array}{l}7 \\
6\end{array}$ & $\begin{array}{l}\text { Macquarie } \\
\text { University }\end{array}$ & $\begin{array}{l}13 \\
6\end{array}$ & Italy & $\begin{array}{l}8 \\
7 \\
3\end{array}$ & $\begin{array}{l}\text { Journal of Knowledge } \\
\text { Management }\end{array}$ \\
\hline 3 & Guthrie, J. & $\begin{array}{l}6 \\
2\end{array}$ & $\begin{array}{l}\text { University } \\
\text { Teknologi Mara }\end{array}$ & $\begin{array}{l}10 \\
6\end{array}$ & $\begin{array}{l}\text { United } \\
\text { States }\end{array}$ & $\begin{array}{l}8 \\
2 \\
8\end{array}$ & $\begin{array}{l}\text { International journal of learning } \\
\text { and Intellectual Capital }\end{array}$ \\
\hline 4 & $\begin{array}{l}\text { Cegarra- } \\
\text { Navarro, } \\
\text { J.G. }\end{array}$ & $\begin{array}{l}4 \\
6\end{array}$ & $\begin{array}{l}\text { Lappeenranta-Lahti } \\
\text { University of } \\
\text { Technology LUT }\end{array}$ & $\begin{array}{l}10 \\
2\end{array}$ & Spain & $\begin{array}{l}7 \\
8 \\
3\end{array}$ & Sustainability Switzerland \\
\hline 5 & $\begin{array}{l}\text { Grimaldi, } \\
\text { M. }\end{array}$ & $\begin{array}{l}3 \\
4\end{array}$ & $\begin{array}{l}\text { Universiti Utara } \\
\text { Malaysai }\end{array}$ & 79 & Australia & $\begin{array}{l}7 \\
6 \\
5\end{array}$ & $\begin{array}{l}\text { Knowledge management } \\
\text { research and practice }\end{array}$ \\
\hline 6 & Kianto, A. & $\begin{array}{l}3 \\
3\end{array}$ & $\begin{array}{l}\text { The University of } \\
\text { Sydney }\end{array}$ & 78 & Malaysia & $\begin{array}{l}5 \\
8 \\
9\end{array}$ & Management decision \\
\hline 7 & $\begin{array}{l}\text { Schiuma, } \\
\text { G. }\end{array}$ & $\begin{array}{l}3 \\
3\end{array}$ & University of Padua & 74 & China & $\begin{array}{l}4 \\
5 \\
6\end{array}$ & $\begin{array}{l}\text { Journal of Information and } \\
\text { Knowledge Management }\end{array}$ \\
\hline 8 & $\begin{array}{l}\text { Serenko, } \\
\text { A. }\end{array}$ & $\begin{array}{l}3 \\
2\end{array}$ & $\begin{array}{l}\text { Tampere University } \\
\text { of Technology }\end{array}$ & 73 & Taiwan & $\begin{array}{l}4 \\
1 \\
6\end{array}$ & Measuring Business Excellence \\
\hline 9 & Roos, G. & $\begin{array}{l}3 \\
1\end{array}$ & $\begin{array}{l}\text { Polytechnic } \\
\text { University of } \\
\text { Cartagena }\end{array}$ & 64 & Finland & $\begin{array}{l}3 \\
8 \\
8\end{array}$ & $\begin{array}{l}\text { Knowledge and Process } \\
\text { Management }\end{array}$ \\
\hline $\begin{array}{l}1 \\
0\end{array}$ & Kong, E. & $\begin{array}{l}3 \\
0\end{array}$ & $\begin{array}{l}\text { Bucharest } \\
\text { University of } \\
\text { Economic Studies }\end{array}$ & 63 & Canada & $\begin{array}{l}3 \\
6 \\
5\end{array}$ & Journal of Business Research \\
\hline $\begin{array}{l}1 \\
1\end{array}$ & Cricelli, L. & $\begin{array}{l}2 \\
9\end{array}$ & RMIT University & 60 & India & $\begin{array}{l}3 \\
1 \\
3\end{array}$ & Meditari Accountancy Research \\
\hline $\begin{array}{l}1 \\
2\end{array}$ & $\begin{array}{l}\text { Bolisani, } \\
\text { E. }\end{array}$ & $\begin{array}{l}2 \\
8\end{array}$ & $\begin{array}{l}\text { University of } \\
\text { Cassino }\end{array}$ & 59 & Iran & $\begin{array}{l}3 \\
1 \\
3\end{array}$ & $\begin{array}{l}\text { International Journal of } \\
\text { Productivity Performance and } \\
\text { Management }\end{array}$ \\
\hline
\end{tabular}




\begin{tabular}{|c|c|c|c|c|c|c|c|}
\hline $\mathbf{R}$ & $\begin{array}{l}\text { Author } \\
\text { Name }\end{array}$ & $\begin{array}{l}\mathbf{T} \\
\mathbf{P}\end{array}$ & Institutes & TP & Country & $\begin{array}{l}\mathbf{T} \\
\mathbf{P}\end{array}$ & Journal \\
\hline 1 & $\begin{array}{l}\text { Secundo, } \\
\text { G. }\end{array}$ & $\begin{array}{l}2 \\
8\end{array}$ & $\begin{array}{l}\text { University of } \\
\text { Castilla-La Mancha: } \\
\text { Ciudad Real } \\
\text { Campus }\end{array}$ & 58 & Germany & $\begin{array}{l}2 \\
2 \\
9\end{array}$ & $\begin{array}{l}\text { Accounting Auditing and } \\
\text { Accountability Journal }\end{array}$ \\
\hline 1 & $\begin{array}{l}\text { Kasemsap } \\
\text {, K. }\end{array}$ & $\begin{array}{l}2 \\
7\end{array}$ & $\begin{array}{l}\text { National Research } \\
\text { University }\end{array}$ & 56 & Portugal & $\begin{array}{l}2 \\
6 \\
4\end{array}$ & $\begin{array}{l}\text { Corporate Ownership and } \\
\text { Control }\end{array}$ \\
\hline 1 & $\begin{array}{l}\text { Bratianu, } \\
\text { C. }\end{array}$ & $\begin{array}{l}2 \\
5\end{array}$ & $\begin{array}{l}\text { University of } \\
\text { Calabria }\end{array}$ & 54 & Indonesia & $\begin{array}{l}2 \\
5 \\
6\end{array}$ & Espacios \\
\hline 1 & Durst, S.. & $\begin{array}{l}2 \\
5\end{array}$ & $\begin{array}{l}\text { Cranfield School of } \\
\text { Management }\end{array}$ & 54 & Brazil & $\begin{array}{l}2 \\
3 \\
1\end{array}$ & $\begin{array}{l}\text { International Journal of } \\
\text { Technology Management }\end{array}$ \\
\hline 7 & $\begin{array}{l}\text { Lonnqvist } \\
\text {, A. }\end{array}$ & $\begin{array}{l}2 \\
5\end{array}$ & $\begin{array}{l}\text { University of Beira } \\
\text { Interior }\end{array}$ & 53 & France & $\begin{array}{l}1 \\
9 \\
1\end{array}$ & $\begin{array}{l}\text { Technological Forecasting and } \\
\text { Social Change }\end{array}$ \\
\hline 8 & $\begin{array}{l}\text { Abeyseke } \\
\text { ra, l. }\end{array}$ & $\begin{array}{l}2 \\
4\end{array}$ & $\begin{array}{l}\text { University of } \\
\text { Technology } \\
\text { Malaysia }\end{array}$ & 53 & $\begin{array}{l}\text { Netherlan } \\
\text { ds }\end{array}$ & $\begin{array}{l}1 \\
3 \\
1\end{array}$ & $\begin{array}{l}\text { International Journal of } \\
\text { Knowledge-based Development }\end{array}$ \\
\hline 9 & $\begin{array}{l}\text { Akhavan, } \\
\text { P. }\end{array}$ & $\begin{array}{l}2 \\
4\end{array}$ & $\begin{array}{l}\text { University of } \\
\text { Salento }\end{array}$ & 53 & Sweden & $\begin{array}{l}1 \\
7 \\
0\end{array}$ & Journal of Cleaner Production \\
\hline 0 & $\begin{array}{l}\text { Nielsen, } \\
\text { C. }\end{array}$ & $\begin{array}{l}2 \\
4\end{array}$ & $\begin{array}{l}\text { University of } \\
\text { Malaya }\end{array}$ & 50 & Thailand & $\begin{array}{l}1 \\
6 \\
6\end{array}$ & Vine \\
\hline 1 & Veltri, S. & $\begin{array}{l}2 \\
3\end{array}$ & $\begin{array}{l}\text { Hong Kong } \\
\text { Polytechnic } \\
\text { University }\end{array}$ & 50 & $\begin{array}{l}\text { South } \\
\text { Africa }\end{array}$ & $\begin{array}{l}1 \\
6 \\
1\end{array}$ & Expert Systems with Applications \\
\hline 2 & $\begin{array}{l}\text { Massaro, } \\
\text { M. }\end{array}$ & $\begin{array}{l}2 \\
2\end{array}$ & $\begin{array}{l}\text { University of } \\
\text { Science, Malaysia }\end{array}$ & 49 & $\begin{array}{l}\text { Russian } \\
\text { Federatio } \\
\mathrm{n}\end{array}$ & $\begin{array}{l}1 \\
5 \\
9\end{array}$ & Learning organization \\
\hline 3 & $\begin{array}{l}\text { Cocosila, } \\
\text { M. }\end{array}$ & $\begin{array}{l}2 \\
1\end{array}$ & $\begin{array}{l}\text { Sapienza University } \\
\text { of Rome }\end{array}$ & 49 & $\begin{array}{l}\text { New } \\
\text { Zealand }\end{array}$ & $\begin{array}{l}1 \\
4 \\
3\end{array}$ & $\begin{array}{l}\text { International journal of } \\
\text { innovation management }\end{array}$ \\
\hline 2 & Joia, L.A. & $\begin{array}{l}2 \\
0\end{array}$ & University of Vigo & 48 & Pakistan & $\begin{array}{l}1 \\
3 \\
6\end{array}$ & Journal of Business Ethics \\
\hline
\end{tabular}


R Author T Institutes Name

2 Marr, B. 2 Islamic Azad

$5 \quad 0$ University
TP Country

T Journal

$P$

48

48 Poland

1 Intangible capital

2

9

Source: authors compilation from Scopus 
Table 3. Most productive authors in JIC and their Citation Structure

\begin{tabular}{|c|c|c|c|c|c|c|c|c|c|c|c|c|c|}
\hline \multirow[t]{2}{*}{$\mathbf{R}$} & \multirow[b]{2}{*}{ Author } & \multirow[t]{2}{*}{ Affiliation } & \multirow[b]{2}{*}{ NP } & \multirow{2}{*}{$\begin{array}{c}\text { PY } \\
\text { Start }\end{array}$} & \multirow[b]{2}{*}{ TC } & \multirow[b]{2}{*}{$H$ index } & \multirow[b]{2}{*}{ G index } & \multirow{2}{*}{$\begin{array}{c}\text { M } \\
\text { index }\end{array}$} & \multicolumn{5}{|c|}{ Number of articles } \\
\hline & & & & & & & & & $\geq 100$ & $\geq 50$ & $\geq 20$ & $\geq 10$ & $\geq 5$ \\
\hline 1 & DUMAY J & $\begin{array}{l}\text { Macquarie } \\
\text { University, } \\
\text { Australia }\end{array}$ & 29 & 2011 & 1118 & 18 & 29 & 1.8 & 3 & 8 & 9 & 5 & 3 \\
\hline 2 & BONTIS N & $\begin{array}{l}\text { McMaster } \\
\text { University, } \\
\text { Canada }\end{array}$ & 26 & 2000 & 2226 & 20 & 26 & 0.95 & 3 & 6 & 10 & 3 & 0 \\
\hline 3 & GUTHRIE J & $\begin{array}{l}\text { Macquarie } \\
\text { University, } \\
\text { Australia }\end{array}$ & 18 & 2000 & 2303 & 16 & 18 & 0.76 & 5 & 2 & 7 & 2 & 0 \\
\hline 4 & ROOS G & $\begin{array}{l}\text { University } \\
\text { of South } \\
\text { Australia, } \\
\text { Australia }\end{array}$ & 10 & 2001 & 372 & 8 & 10 & 0.4 & 0 & 3 & 3 & 2 & 1 \\
\hline 5 & CHATZKEL J & $\begin{array}{l}\text { Jay } \\
\text { Chatzkel } \\
\text { Progressive } \\
\text { Practices, } \\
\text { Virginia, } \\
\text { USA }\end{array}$ & 10 & 2000 & 242 & 6 & 10 & 0.28 & 1 & 0 & 2 & 2 & 4 \\
\hline 6 & ABEYSEKERA I & $\begin{array}{l}\text { Charles } \\
\text { Darwin } \\
\text { University, } \\
\text { Australia }\end{array}$ & 7 & 2006 & 421 & 7 & 7 & 0.46 & 0 & 5 & 2 & 0 & 0 \\
\hline 7 & MOURITSEN J & $\begin{array}{l}\text { Copenhagen } \\
\text { Business } \\
\text { School, } \\
\text { Denmark } \\
\end{array}$ & 7 & 2001 & 402 & 7 & 7 & 0.35 & 1 & 2 & 1 & 1 & 1 \\
\hline 8 & SECUNDO G & $\begin{array}{l}\text { University } \\
\text { of Salento, } \\
\text { Italy }\end{array}$ & 7 & 2010 & 290 & 7 & 7 & 0.63 & 0 & 3 & 2 & 2 & 0 \\
\hline 9 & JOHANSON U & $\begin{array}{l}\text { Karolinska } \\
\text { Institute, } \\
\text { Stockholm, } \\
\text { Sweden }\end{array}$ & 7 & 2003 & 230 & 7 & 7 & 0.38 & 0 & 1 & 4 & 2 & 0 \\
\hline 10 & GIULIANI M & $\begin{array}{l}\text { Marche } \\
\text { Polytechnic } \\
\text { University, } \\
\text { Italy }\end{array}$ & 7 & 2009 & 139 & 6 & 7 & 0.5 & 0 & 0 & 2 & 4 & 1 \\
\hline 11 & BUKH PN & $\begin{array}{l}\text { University } \\
\text { of Aarhus, } \\
\text { Aarhus, } \\
\text { Denmark }\end{array}$ & 6 & 2001 & 382 & 6 & 6 & 0.3 & 1 & 1 & 3 & 0 & 0 \\
\hline 12 & EDVINSSON L & $\begin{array}{l}\text { Lund } \\
\text { University, } \\
\text { Lund, } \\
\text { Sweden } \\
\end{array}$ & 6 & 2000 & 291 & 6 & 6 & 0.28 & 0 & 3 & 2 & 1 & 0 \\
\hline 13 & BOUNFOUR A & $\begin{array}{l}\text { University } \\
\text { of Paris- } \\
\text { Sud, France }\end{array}$ & 6 & 2003 & 132 & 3 & 6 & 0.16 & 0 & 0 & 1 & 1 & 1 \\
\hline 14 & NIELSEN C & $\begin{array}{l}\text { Aalborg } \\
\text { University, } \\
\text { Denmark }\end{array}$ & 6 & 2006 & 119 & 6 & 6 & 0.4 & 0 & 0 & 3 & 2 & 1 \\
\hline 15 & CRICELLI L & $\begin{array}{l}\text { University } \\
\text { of Cassino } \\
\text { and } \\
\text { Southern }\end{array}$ & 6 & 2012 & 116 & 4 & 6 & 0.44 & 0 & 1 & 2 & 0 & 0 \\
\hline
\end{tabular}




\begin{tabular}{|c|c|c|c|c|c|c|c|c|c|c|c|c|c|}
\hline & & $\begin{array}{l}\text { Lazio, } \\
\text { Cassino, } \\
\text { Italy }\end{array}$ & & & & & & & & & & & \\
\hline 16 & GRIMALDI M & $\begin{array}{l}\text { University } \\
\text { of Cassino } \\
\text { and } \\
\text { Southern } \\
\text { Lazio, Italy }\end{array}$ & 6 & 2012 & 116 & 4 & 6 & 0.44 & 0 & 1 & 2 & 0 & 0 \\
\hline 17 & PETTY R & $\begin{array}{l}\text { Macquarie } \\
\text { University, } \\
\text { Australia }\end{array}$ & 5 & 2000 & 1718 & 5 & 5 & 0.23 & 4 & 0 & 1 & 0 & 0 \\
\hline 18 & MARR B & $\begin{array}{l}\text { Cranfield } \\
\text { University, } \\
\text { UK }\end{array}$ & 5 & 2003 & 564 & 5 & 5 & 0.27 & 3 & 0 & 2 & 0 & 0 \\
\hline 19 & SCHIUMA G & $\begin{array}{l}\text { University } \\
\text { of } \\
\text { Basilicata, } \\
\text { Italy }\end{array}$ & 5 & 2004 & 351 & 5 & 5 & 0.29 & 1 & 1 & 2 & 1 & 0 \\
\hline 20 & ANDRIESSEN D & $\begin{array}{l}\text { HU } \\
\text { University } \\
\text { of Applied } \\
\text { Sciences } \\
\text { Utrecht, } \\
\text { Netherlands }\end{array}$ & 5 & 2001 & 326 & 4 & 5 & 0.2 & 1 & 1 & 2 & 0 & 0 \\
\hline 21 & PIKE $S$ & $\begin{array}{l}\text { Intellectual } \\
\text { Capital } \\
\text { Services } \\
\text { Ltd, UK }\end{array}$ & 5 & 2001 & 300 & 5 & 5 & 0.25 & 0 & 4 & 1 & 0 & 0 \\
\hline 22 & DAVEY H & $\begin{array}{l}\text { University } \\
\text { of Waikato, } \\
\text { New } \\
\text { Zealand }\end{array}$ & 5 & 2009 & 205 & 5 & 5 & 0.41 & 0 & 2 & 1 & 2 & 0 \\
\hline 23 & O DONNELL D & $\begin{array}{l}\text { The } \\
\text { Intellectual } \\
\text { Capital } \\
\text { Research } \\
\text { Institute of } \\
\text { Ireland, } \\
\text { Ireland }\end{array}$ & 5 & 2000 & 179 & $\mathrm{Na}$ & $\mathrm{Na}$ & $\mathrm{Na}$ & 0 & 1 & 4 & 0 & 0 \\
\hline 24 & KONG E & $\begin{array}{l}\text { University } \\
\text { of Southern } \\
\text { Queensland, } \\
\text { Australia }\end{array}$ & 5 & 2007 & 171 & 5 & 5 & 0.35 & 0 & 1 & 3 & 1 & 0 \\
\hline 25 & LNNQVIST A & $\begin{array}{l}\text { Tampere } \\
\text { University, } \\
\text { Finland }\end{array}$ & 5 & 2007 & 164 & 5 & 5 & 0.35 & 0 & 1 & 3 & 1 & 0 \\
\hline 26 & CHIUCCHI MS & $\begin{array}{l}\text { Marche } \\
\text { Polytechnic } \\
\text { University, } \\
\text { Italy }\end{array}$ & 5 & 2013 & 121 & 5 & 5 & 0.625 & 0 & 0 & 4 & 2 & 1 \\
\hline 27 & ABHAYAWANSA S & $\begin{array}{l}\text { Swinburne } \\
\text { University } \\
\text { of } \\
\text { Technology, } \\
\text { Australia }\end{array}$ & 5 & 2009 & 66 & 3 & 5 & 0.25 & 0 & 0 & 3 & 1 & 0 \\
\hline
\end{tabular}

$\mathrm{R}=$ Rank; NP: Total publication in JIC; TC: Total citations; C/P: Citation per publication; $\mathrm{h}$ : $\mathrm{h}$ - index; $\geq 100$, $\geq 50, \geq 20, \geq 10, \geq 5$, Number of articles with at least 100,50, 20, 10, and 5 citations respectively. 
Table 4. The 25 Most influential paper published in JIC

R Article title

1 Intellectual capital and business performance in Malaysian industries

2 Intellectual capital literature review: Measurement, reporting and management

3 An empirical investigation of the relationship between intellectual capital and firms' market value and financial performance

4 Using content analysis as a research method to inquire into intellectual capital reporting

5 A knowledge-based theory of the firm to guide in strategy formulation

6 Intellectual capital: Australian annual reporting practices

7 Examining the link between knowledge management practices and types of innovation

8 Intellectual capital and traditional measures of corporate performance

9 Intellectual capital ROI: A causal map of human capital antecedents and consequents

10 Measuring intellectual capital: A new model and empirical study

11 National Intellectual Capital Index: A United Nations initiative for the Arab region

\section{Author/s}

Bontis,

N., William Chua

Chong,

K., Richardson,

S.

Petty,

6292000

29.76

R., Guthrie, J.

Chen, M.-C.,

Cheng, S.-J.,

Hwang, $Y$.

Guthrie, J.,

$482 \quad 2004$

28.23

Petty, R.,

Yongvanich, K.,

Ricceri, F.

Sveiby, K.-E.

$\begin{array}{lll}417 & 2001 & 20.8\end{array}$

Guthrie, J.,

$374 \quad 2000$

17.76

Petty, R.

Darroch, J.,

3652002

19.21

Mcnaughton, $\mathrm{R}$.

Firer, S.,

$\begin{array}{lll}358 & 2003 \quad 19.83\end{array}$

Mitchell

Williams, S.

Bontis, N., Fitz-

$\begin{array}{lll}354 & 2002 \quad 18.63\end{array}$

enz, J.

Chen, J., Yuan

$303 \quad 2004$

$X i e, \mathrm{H}$.

Bontis, N.

$296 \quad 2004$ 
12 Italian annual intellectual capital disclosure: An empirical analysis

13 Difficulties in diffusion of tacit knowledge in organizations

14 Intellectual capital and firm performance of US multinational firms: A study of the resource-based and stakeholder views

15 Value network analysis and value conversion of tangible and intangible assets

16 Intellectual capital and financial returns of companies

17 The voluntary reporting of intellectual capital: Comparing evidence from Hong Kong and Australia

18 Intellectual capital and performance in causal models. Evidence from the information technology industry in Taiwan

19 Analysing value added as an indicator of intellectual capital and its consequences on company performance

20 The dynamics of value creation: Mapping your intellectual performance drivers

21 Why do firms measure their intellectual capital?

22 The management, measurement and the reporting of intellectual capital

23 Is intellectual capital performance and disclosure practices related?

24 IC valuation and measurement: Classifying the state of the art

25 The impact of intellectual capital on firms' market value and financial performance
Bozzolan, S.,

2802003

15.50

Favotto, F.,

Ricceri, F.

Haldin-Herrgard, 263200012.52 $\mathrm{T}$.

Riahi-Belkaoui,

$\begin{array}{lll}230 & 2003 & 12.77\end{array}$

A.

Allee, $\mathrm{V}$.

$229 \quad 2007 \quad 17.61$

Tan, H.P.,

$229 \quad 2008 \quad 15.92$

Plowman, D.,

Hancock, P.

Guthrie, J.,

$214 \quad 2006 \quad 14.2$

Petty, R.,

Ricceri, F.

Wang, W.-Y., $\quad 210200513.12$

Chang, $\mathrm{C}$.

Zéghal, D.,

$209 \quad 2010 \quad 18.90$

Maaloul, A.

Marr, B., Neely,

$203 \quad 2004 \quad 11.94$

A., Schiuma, G.

Marr, B., Gray, $2022003 \quad 11.22$

D., Neely,A.

Guthrie, J.

19920019.90

Mitchell

$192 \quad 20019.55$

Williams, S.

Andriessen, D. $\quad 188 \quad 2004 \quad 11.05$

Maditinos, D.,

$\begin{array}{lll}185 & 2011 \quad 18.40\end{array}$

Chatzoudes, D.,

Tsairidis, C.,

Theriou, G.

Notes: $\mathrm{R}=\mathrm{Rank} ; \mathrm{TC}=$ Total citations; $\mathrm{C} / \mathrm{Y}=$ Citations per year. 
Table 5: Most cited article in JIC from 2000-2020

\begin{tabular}{|c|c|c|c|c|c|}
\hline Rank & Article & Author & Journal & YoP & Citations \\
\hline 1 & $\begin{array}{l}\text { INTELLECTUAL } \\
\text { CAPITAL: AN } \\
\text { EXPLORATORY STUDY } \\
\text { THAT DEVELOPS } \\
\text { MEASURES AND } \\
\text { MODELS }\end{array}$ & BONTIS, N., & $\begin{array}{l}\text { MANAGEMENT } \\
\text { DECISION }\end{array}$ & 1998 & 109 \\
\hline 2 & $\begin{array}{l}\text { INTELLECTUAL } \\
\text { CAPITAL LITERATURE } \\
\text { REVIEW: } \\
\text { MEASUREMENT, } \\
\text { REPORTING AND } \\
\text { MANAGEMENT }\end{array}$ & $\begin{array}{l}\text { PETTY, R., } \\
\text { GUTHRIE, J., }\end{array}$ & $\begin{array}{l}\text { JOURNAL OF } \\
\text { INTELLECTUAL } \\
\text { CAPITAL }\end{array}$ & 2000 & 74 \\
\hline 3 & $\begin{array}{l}\text { ASSESSING } \\
\text { KNOWLEDGE ASSETS: } \\
\text { A REVIEW OF THE } \\
\text { MODELS USED TO } \\
\text { MEASURE } \\
\text { INTELLECTUAL } \\
\text { CAPITAL } \\
\end{array}$ & BONTIS, N., & $\begin{array}{l}\text { INTERNATIONAL } \\
\text { JOURNAL OF } \\
\text { MANAGEMENT } \\
\text { REVIEWS }\end{array}$ & 2001 & 69 \\
\hline 4 & $\begin{array}{l}\text { INTELLECTUAL } \\
\text { CAPITAL: AUSTRALIAN } \\
\text { ANNUAL REPORTING } \\
\text { PRACTICES }\end{array}$ & $\begin{array}{l}\text { GUTHRIE, J., } \\
\text { PETTY, R., }\end{array}$ & $\begin{array}{l}\text { JOURNAL OF } \\
\text { INTELLECTUAL } \\
\text { CAPITAL }\end{array}$ & 2000 & 58 \\
\hline 5 & $\begin{array}{l}\text { INTELLECTUAL } \\
\text { CAPITAL RESEARCH: A } \\
\text { CRITICAL } \\
\text { EXAMINATION OF THE } \\
\text { THIRD STAGE } \\
\end{array}$ & $\begin{array}{l}\text { DUMAY, J., } \\
\text { GARANINA, T., }\end{array}$ & $\begin{array}{l}\text { JOURNAL OF } \\
\text { INTELLECTUAL } \\
\text { CAPITAL }\end{array}$ & 2013 & 56 \\
\hline 6 & $\begin{array}{l}\text { DEVELOPING } \\
\text { INTELLECTUAL } \\
\text { CAPITAL AT SKANDIA }\end{array}$ & EDVINSSON, L., & $\begin{array}{l}\text { LONG RANGE } \\
\text { PLANNING }\end{array}$ & 1997 & 42 \\
\hline 7 & $\begin{array}{l}\text { A CRITICAL } \\
\text { REFLECTION ON THE } \\
\text { FUTURE OF } \\
\text { INTELLECTUAL } \\
\text { CAPITAL: FROM } \\
\text { REPORTING TO } \\
\text { DISCLOSURE }\end{array}$ & DUMAY, J., & $\begin{array}{l}\text { JOURNAL OF } \\
\text { INTELLECTUAL } \\
\text { CAPITAL }\end{array}$ & 2016 & 41 \\
\hline 8 & $\begin{array}{l}\text { USING CONTENT } \\
\text { ANALYSIS AS A } \\
\text { RESEARCH METHOD } \\
\text { TO INQUIRE INTO } \\
\text { INTELLECTUAL } \\
\text { CAPITAL REPORTING }\end{array}$ & $\begin{array}{l}\text { GUTHRIE, J., } \\
\text { PETTY, R., } \\
\text { YONGVANICH, } \\
\text { K., RICCERI, F., }\end{array}$ & $\begin{array}{l}\text { JOURNAL OF } \\
\text { INTELLECTUAL } \\
\text { CAPITAL }\end{array}$ & 2004 & 41 \\
\hline 9 & $\begin{array}{l}\text { PROBLEMATISING } \\
\text { INTELLECTUAL } \\
\text { CAPITAL RESEARCH: } \\
\text { OSTENSIVE VERSUS } \\
\text { PERFORMATIVE IC }\end{array}$ & MOURITSEN, J., & $\begin{array}{l}\text { ACCOUNTING, } \\
\text { AUDITING \& } \\
\text { ACCOUNTABILITY } \\
\text { JOURNAL }\end{array}$ & 2006 & 41 \\
\hline 10 & $\begin{array}{l}\text { SOCIAL CAPITAL, } \\
\text { INTELLECTUAL } \\
\text { CAPITAL, AND THE } \\
\text { ORGANIZATIONAL } \\
\text { ADVANTAGE (1998), } 23 \\
(2), \text { PP. 242-266 }\end{array}$ & $\begin{array}{l}\text { NAHAPIET, J., } \\
\text { GHOSHAL, S., }\end{array}$ & $\begin{array}{l}\text { ACADEMY OF } \\
\text { MANAGEMENT } \\
\text { REVIEW }\end{array}$ & 1998 & 38 \\
\hline
\end{tabular}




\begin{tabular}{|c|c|c|c|c|c|}
\hline 11 & $\begin{array}{l}\text { THE INFLUENCE OF } \\
\text { INTELLECTUAL } \\
\text { CAPITAL ON THE } \\
\text { TYPES OF INNOVATIVE } \\
\text { CAPABILITIES }\end{array}$ & $\begin{array}{l}\text { SUBRAMANIAM, } \\
\text { M., YOUNDT, } \\
\text { M.A., }\end{array}$ & $\begin{array}{l}\text { ACADEMY OF } \\
\text { MANAGEMENT } \\
\text { JOURNAL }\end{array}$ & 2005 & 36 \\
\hline 12 & $\begin{array}{l}\text { DEVELOPING A MODEL } \\
\text { FOR MANAGING } \\
\text { INTELLECTUAL } \\
\text { CAPITAL } \\
\end{array}$ & $\begin{array}{l}\text { EDVINSSON, L., } \\
\text { SULLIVAN, P., }\end{array}$ & $\begin{array}{l}\text { EUROPEAN } \\
\text { MANAGEMENT } \\
\text { JOURNAL }\end{array}$ & 1996 & 35 \\
\hline 13 & $\begin{array}{l}\text { INTELLECTUAL } \\
\text { CAPITAL AND } \\
\text { TRADITIONAL } \\
\text { MEASURES OF } \\
\text { CORPORATE } \\
\text { PERFORMANCE }\end{array}$ & $\begin{array}{l}\text { FIRER, S., } \\
\text { WILLIAMS, S.M., }\end{array}$ & $\begin{array}{l}\text { JOURNAL OF } \\
\text { INTELLECTUAL } \\
\text { CAPITAL }\end{array}$ & 2003 & 35 \\
\hline 14 & $\begin{array}{l}\text { REFLECTIONS AND } \\
\text { PROJECTIONS: A } \\
\text { DECADE OF } \\
\text { INTELLECTUAL } \\
\text { CAPITAL ACCOUNTING } \\
\text { RESEARCH }\end{array}$ & $\begin{array}{l}\text { GUTHRIE, J., } \\
\text { RICCERI, F., } \\
\text { DUMAY, J., }\end{array}$ & $\begin{array}{l}\text { THE BRITISH } \\
\text { ACCOUNTING } \\
\text { REVIEW }\end{array}$ & 2012 & 32 \\
\hline 15 & $\begin{array}{l}\text { THE PROJECT OF } \\
\text { INTELLECTUAL } \\
\text { CAPITAL DISCLOSURE: } \\
\text { RESEARCHING THE } \\
\text { RESEARCH }\end{array}$ & $\begin{array}{l}\text { ABEYSEKERA, } \\
\text { I., }\end{array}$ & $\begin{array}{l}\text { JOURNAL OF } \\
\text { INTELLECTUAL } \\
\text { CAPITAL }\end{array}$ & 2006 & 31 \\
\hline 16 & $\begin{array}{l}\text { NATIONAL } \\
\text { INTELLECTUAL } \\
\text { CAPITAL INDEX: A } \\
\text { UNITED NATIONS } \\
\text { INITIATIVE FOR THE } \\
\text { ARAB REGION }\end{array}$ & BONTIS, N., & $\begin{array}{l}\text { JOURNAL OF } \\
\text { INTELLECTUAL } \\
\text { CAPITAL }\end{array}$ & 2004 & 31 \\
\hline 17 & $\begin{array}{l}\text { ITALIAN ANNUAL } \\
\text { INTELLECTUAL } \\
\text { CAPITAL DISCLOSURE: } \\
\text { AN EMPIRICAL } \\
\text { ANALYSIS }\end{array}$ & $\begin{array}{l}\text { BOZZOLAN, S., } \\
\text { FAVOTTO, F., } \\
\text { RICCERI, F., }\end{array}$ & $\begin{array}{l}\text { JOURNAL OF } \\
\text { INTELLECTUAL } \\
\text { CAPITAL }\end{array}$ & 2003 & 31 \\
\hline 18 & $\begin{array}{l}\text { REPORTING } \\
\text { INTELLECTUAL } \\
\text { CAPITAL IN ANNUAL } \\
\text { REPORTS: EVIDENCE } \\
\text { FROM IRELAND (2001) }\end{array}$ & BRENNAN, N., & $\begin{array}{l}\text { ACCOUNTING, } \\
\text { AUDITING \& } \\
\text { ACCOUNTABILITY } \\
\text { JOURNAL }\end{array}$ & 2001 & 31 \\
\hline 19 & $\begin{array}{l}\text { THE VOLUNTARY } \\
\text { REPORTING OF } \\
\text { INTELLECTUAL } \\
\text { CAPITAL: COMPARING } \\
\text { EVIDENCE FROM HONG } \\
\text { KONG AND AUSTRALIA } \\
\text { (2006) }\end{array}$ & $\begin{array}{l}\text { GUTHRIE, J., } \\
\text { PETTY, R., } \\
\text { RICCERI, F., }\end{array}$ & $\begin{array}{l}\text { JOURNAL OF } \\
\text { INTELLECTUAL } \\
\text { CAPITAL }\end{array}$ & 2006 & 31 \\
\hline 20 & $\begin{array}{l}\text { GRAND THEORIES AS } \\
\text { BARRIERS TO USING IC } \\
\text { CONCEPTS }\end{array}$ & DUMAY, J., & $\begin{array}{l}\text { JOURNAL OF } \\
\text { INTELLECTUAL } \\
\text { CAPITAL }\end{array}$ & 2012 & 29 \\
\hline 21 & $\begin{array}{l}\text { THE DYNAMICS OF } \\
\text { VALUE CREATION: } \\
\text { MAPPING YOUR } \\
\text { INTELLECTUAL } \\
\text { PERFORMANCE } \\
\text { DRIVERS (2004) }\end{array}$ & $\begin{array}{l}\text { MARR, B., } \\
\text { SCHIUMA, G., } \\
\text { NEELY, A., }\end{array}$ & $\begin{array}{l}\text { JOURNAL OF } \\
\text { INTELLECTUAL } \\
\text { CAPITAL }\end{array}$ & 2004 & 29 \\
\hline
\end{tabular}




\begin{tabular}{|c|c|c|c|c|c|}
\hline 22 & $\begin{array}{l}\text { AN EMPIRICAL } \\
\text { INVESTIGATION OF } \\
\text { ANNUAL REPORTING } \\
\text { TRENDS OF } \\
\text { INTELLECTUAL } \\
\text { CAPITAL IN SRI LANKA } \\
(2005)\end{array}$ & $\begin{array}{l}\text { ABEYSEKERA, } \\
\text { I., GUTHRIE, J., }\end{array}$ & $\begin{array}{l}\text { CRITICAL } \\
\text { PERSPECTIVES ON } \\
\text { ACCOUNTING }\end{array}$ & 2005 & 28 \\
\hline 23 & $\begin{array}{l}\text { THE MANAGEMENT, } \\
\text { MEASUREMENT AND } \\
\text { THE REPORTING OF } \\
\text { INTELLECTUAL } \\
\text { CAPITAL }\end{array}$ & GUTHRIE, J., & $\begin{array}{l}\text { JOURNAL OF } \\
\text { INTELLECTUAL } \\
\text { CAPITAL }\end{array}$ & 2001 & 27 \\
\hline 24 & $\begin{array}{l}\text { INTELLECTUAL } \\
\text { CAPITAL PROFILES: AN } \\
\text { EXAMINATION OF } \\
\text { INVESTMENTS AND } \\
\text { RETURNS }\end{array}$ & $\begin{array}{l}\text { YOUNDT, M.A., } \\
\text { SUBRAMANIAM, } \\
\text { M., SNELL, S.A., }\end{array}$ & $\begin{array}{l}\text { JOURNAL OF } \\
\text { MANAGEMENT } \\
\text { STUDIES }\end{array}$ & 2004 & 27 \\
\hline 25 & $\begin{array}{l}\text { INTELLECTUAL } \\
\text { CAPITAL ROI: A } \\
\text { CAUSAL MAP OF } \\
\text { HUMAN CAPITAL } \\
\text { ANTECEDENTS AND } \\
\text { CONSEQUENTS }\end{array}$ & $\begin{array}{l}\text { BONTIS, N., } \\
\text { FITZ-ENZ, J., }\end{array}$ & $\begin{array}{l}\text { JOURNAL OF } \\
\text { INTELLECTUAL } \\
\text { CAPITAL }\end{array}$ & 2002 & 26 \\
\hline
\end{tabular}

Source: Scopus database; $\mathrm{R}=$ Rank; $\mathrm{TC}=$ Total citations; and TLS=Total link strength, YoP: year of publication.

Table 6. Most Productive Institutions, Countries and Keywords (frequency) in JIC

\begin{tabular}{|c|c|c|c|c|c|c|c|c|}
\hline $\mathbf{R}$ & $\begin{array}{l}\text { University/Organizatio } \\
\text { n }\end{array}$ & $\begin{array}{l}\mathbf{T} \\
\mathbf{P}\end{array}$ & TC & Country & TP & TC & $\begin{array}{l}\text { Authors Key } \\
\text { Words }\end{array}$ & $\begin{array}{l}\text { Frequenc } \\
\text { y }\end{array}$ \\
\hline 1 & Macquarie University & $\begin{array}{l}4 \\
4\end{array}$ & $\begin{array}{l}315 \\
8\end{array}$ & Italy & $\begin{array}{l}12 \\
0\end{array}$ & $\begin{array}{l}584 \\
5\end{array}$ & $\begin{array}{l}\text { Intellectual } \\
\text { Capital }\end{array}$ & 503 \\
\hline 2 & McMaster University & $\begin{array}{l}2 \\
7\end{array}$ & $\begin{array}{l}229 \\
6\end{array}$ & Australia & $\begin{array}{l}10 \\
9\end{array}$ & $\begin{array}{l}432 \\
4\end{array}$ & $\begin{array}{l}\text { Intangible } \\
\text { Asset }\end{array}$ & 120 \\
\hline 3 & $\begin{array}{l}\text { The university of } \\
\text { Sydney }\end{array}$ & $\begin{array}{l}1 \\
7\end{array}$ & $\begin{array}{l}119 \\
5\end{array}$ & $\begin{array}{l}\text { United } \\
\text { States }\end{array}$ & 84 & $\begin{array}{l}360 \\
5\end{array}$ & $\begin{array}{l}\text { Knowledge } \\
\text { Management }\end{array}$ & 85 \\
\hline 4 & $\begin{array}{l}\text { Cranfield school of } \\
\text { management }\end{array}$ & $\begin{array}{l}1 \\
3\end{array}$ & 915 & $\begin{array}{l}\text { United } \\
\text { Kingdom }\end{array}$ & 68 & $\begin{array}{l}210 \\
8\end{array}$ & $\begin{array}{l}\text { Human } \\
\text { Capital }\end{array}$ & 70 \\
\hline 5 & University of Ferrara & $\begin{array}{l}1 \\
3\end{array}$ & 189 & Spain & 66 & $\begin{array}{l}260 \\
5\end{array}$ & Disclosure & 54 \\
\hline 6 & $\begin{array}{l}\text { Autonomous University } \\
\text { of Madrid }\end{array}$ & $\begin{array}{l}1 \\
2\end{array}$ & 669 & Canada & 49 & $\begin{array}{l}389 \\
6\end{array}$ & Innovation & 44 \\
\hline 7 & $\begin{array}{l}\text { Marche Polytechnic } \\
\text { University }\end{array}$ & $\begin{array}{l}1 \\
2\end{array}$ & 281 & Taiwan & 30 & $\begin{array}{l}150 \\
3\end{array}$ & $\begin{array}{l}\text { Measuremen } \\
\mathrm{t}\end{array}$ & 36 \\
\hline
\end{tabular}




\begin{tabular}{|c|c|c|c|c|c|c|c|c|}
\hline $\mathbf{R}$ & $\begin{array}{l}\text { University/Organizatio } \\
\text { n }\end{array}$ & $\begin{array}{l}\mathbf{T} \\
\mathbf{P}\end{array}$ & $\mathrm{TC}$ & Country & TP & TC & $\begin{array}{l}\text { Authors Key } \\
\text { Words }\end{array}$ & $\begin{array}{l}\text { Frequenc } \\
\text { y }\end{array}$ \\
\hline 8 & $\begin{array}{l}\text { National Research } \\
\text { University Higher } \\
\text { School of Economics }\end{array}$ & $\begin{array}{l}1 \\
2\end{array}$ & 109 & Sweden & 28 & 845 & $\begin{array}{l}\text { Intellectual } \\
\text { Property }\end{array}$ & 28 \\
\hline 9 & $\begin{array}{l}\text { National Chengchi } \\
\text { University }\end{array}$ & $\begin{array}{l}1 \\
0\end{array}$ & 929 & Malaysia & 26 & $\begin{array}{l}162 \\
9\end{array}$ & $\begin{array}{l}\text { Integrated } \\
\text { reporting }\end{array}$ & 22 \\
\hline 1 & University of Bologna & 9 & 208 & Finland & 25 & $\begin{array}{l}164 \\
5\end{array}$ & $\begin{array}{l}\text { Financial } \\
\text { performance }\end{array}$ & 21 \\
\hline 1 & University of Cassino & 9 & 191 & India & 21 & 881 & $\begin{array}{l}\text { Financial } \\
\text { reporting }\end{array}$ & 20 \\
\hline 2 & Multimedia University & 8 & $\begin{array}{l}118 \\
2\end{array}$ & $\begin{array}{l}\text { New } \\
\text { Zealand }\end{array}$ & 20 & $\begin{array}{l}111 \\
1\end{array}$ & $\begin{array}{l}\text { Content } \\
\text { analysis }\end{array}$ & 18 \\
\hline 1 & $\begin{array}{l}\text { Copenhagen Business } \\
\text { School }\end{array}$ & 8 & 453 & $\begin{array}{l}\text { Russian } \\
\text { Federation }\end{array}$ & 20 & 477 & Social capital & 18 \\
\hline 1 & $\begin{array}{l}\text { Lappeenranta-Lahti } \\
\text { University of } \\
\text { Technology LUT }\end{array}$ & 8 & 440 & Denmark & 17 & 675 & Knowledge & 17 \\
\hline 1 & University of Salento & 8 & 296 & Portugal & 16 & 207 & $\begin{array}{l}\text { Strategic } \\
\text { management }\end{array}$ & 17 \\
\hline 6 & $\begin{array}{l}\text { University of } \\
\text { Wollongong }\end{array}$ & 8 & 277 & $\begin{array}{l}\text { Netherland } \\
\mathrm{s}\end{array}$ & 15 & 654 & $\begin{array}{l}\text { Annual } \\
\text { reports }\end{array}$ & 16 \\
\hline 7 & University of Vigo & 8 & 197 & Germany & 15 & 588 & $\begin{array}{l}\text { Business } \\
\text { performance }\end{array}$ & 16 \\
\hline 8 & Aalborg University & 8 & 189 & Austria & 14 & 343 & $\begin{array}{l}\text { Intellectual } \\
\text { capital } \\
\text { reporting }\end{array}$ & 16 \\
\hline 9 & $\begin{array}{l}\text { Sapienza University of } \\
\text { Rome }\end{array}$ & 8 & 187 & France & 14 & 339 & Performance & 16 \\
\hline 0 & $\begin{array}{l}\text { Swinburne University of } \\
\text { Technology }\end{array}$ & 8 & 104 & Hong Kong & 12 & $\begin{array}{l}140 \\
1\end{array}$ & $\begin{array}{l}\text { Relational } \\
\text { capital }\end{array}$ & 16 \\
\hline 1 & University of Padua & 7 & $\begin{array}{l}104 \\
9\end{array}$ & Brazil & 12 & 296 & Intangibles & 15 \\
\hline 2 & University of Waikato & 7 & 294 & Ireland & 11 & 441 & $\begin{array}{l}\text { Intellectual } \\
\text { capital } \\
\text { disclosure }\end{array}$ & 15 \\
\hline 2 & Cranefield University & 7 & 289 & $\begin{array}{l}\text { South } \\
\text { Africa }\end{array}$ & 11 & 716 & $\begin{array}{l}\text { Competitive } \\
\text { advantage }\end{array}$ & 13 \\
\hline
\end{tabular}




\begin{tabular}{|c|c|c|c|c|c|c|c|c|}
\hline $\mathbf{R}$ & $\begin{array}{l}\text { University/Organizatio } \\
\mathbf{n}\end{array}$ & $\begin{array}{l}\mathbf{T} \\
\mathbf{P}\end{array}$ & $\mathrm{TC}$ & Country & TP & $\mathrm{TC}$ & $\begin{array}{l}\text { Authors Key } \\
\text { Words }\end{array}$ & $\begin{array}{l}\text { Frequenc } \\
y\end{array}$ \\
\hline 2 & Mälardalen University & 7 & 231 & China & 7 & 343 & Value added & 13 \\
\hline 2 & $\begin{array}{l}\text { University of Castilla-La } \\
\text { Mancha: Ciudad Real } \\
\text { Campus }\end{array}$ & 7 & 219 & Iran & 7 & 138 & $\begin{array}{l}\text { Non-profit } \\
\text { organizations }\end{array}$ & 12 \\
\hline
\end{tabular}

Source: Scopus data base, TC: total citation, TP: total publication 
Table 7: Top 50 articles included in historiograph

\begin{tabular}{|c|c|c|c|c|}
\hline Paper & DOI & Year & LCS & GCS \\
\hline GUTHRIE J, 2000, J INTELLECT CAP & $10.1108 / 14691930010350800$ & 2000 & 78 & 373 \\
\hline BRENNAN N, 2000, J INTELLECT CAP & $10.1108 / 14691930010350792$ & 2000 & 31 & 159 \\
\hline BONTIS N, 2000, J INTELLECT CAP & $10.1108 / 14691930010324188$ & 2000 & 70 & 722 \\
\hline SVEIBY KE, 2001, J INTELLECT CAP & $10.1108 / 14691930110409651$ & 2001 & 19 & 416 \\
\hline GUTHRIE J, 2001, J INTELLECT CAP & $10.1108 / 14691930110380473$ & 2001 & 31 & 198 \\
\hline BONTIS N, 2002, J INTELLECT CAP & $10.1108 / 14691930210435589$ & 2002 & 31 & 354 \\
\hline BOUNFOUR A, 2003, J INTELLECT CAP & $10.1108 / 14691930310487833$ & 2003 & 17 & 82 \\
\hline APRIL KA, 2003, J INTELLECT CAP & $10.1108 / 14691930310472794$ & 2003 & 25 & 123 \\
\hline KAUFMANN L, 2004, J INTELLECT CAP & $10.1108 / 14691930410550354$ & 2004 & 22 & 140 \\
\hline MARR B, 2004, J INTELLECT CAP & $10.1108 / 14691930410533722$ & 2004 & 35 & 203 \\
\hline ANDRIESSEN D, 2004, J INTELLECT CAP & $10.1108 / 14691930410533669$ & 2004 & 23 & 188 \\
\hline GUTHRIE J, 2004, J INTELLECT CAP & $10.1108 / 14691930410533704$ & 2004 & 50 & 480 \\
\hline MAVRIDIS DG, 2004, J INTELLECT CAP & $10.1108 / 14691930410512941$ & 2004 & 19 & 120 \\
\hline BONTIS N, 2004, J INTELLECT CAP & $10.1108 / 14691930410512905$ & 2004 & 36 & 296 \\
\hline CHEN J, 2004, J INTELLECT CAP & $10.1108 / 14691930410513003$ & 2004 & 27 & 303 \\
\hline ABDOLMOHAMMADI MJ, 2005, J INTELLECT CAP & $10.1108 / 14691930510611139$ & 2005 & 24 & 136 \\
\hline GHO PC, 2005, J INTELLECT CAP & $10.1108 / 14691930510611120$ & 2005 & 26 & 166 \\
\hline WANG WY, 2005, J INTELLECT CAP & $10.1108 / 14691930510592816$ & 2005 & 23 & 210 \\
\hline CHEN MC, 2005, J INTELLECT CAP & $10.1108 / 14691930510592771$ & 2005 & 35 & 484 \\
\hline GUTHRIE J, 2006, J INTELLECT CAP & $10.1108 / 14691930610661890$ & 2006 & 36 & 213 \\
\hline ABEYSEKERA I, 2006, J INTELLECT CAP & $10.1108 / 14691930610639778$ & 2006 & 37 & 96 \\
\hline NAZARI JA, 2007, J INTELLECT CAP & $10.1108 / 14691930710830774$ & 2007 & 18 & 93 \\
\hline KUJANSIVU P, 2007, J INTELLECT CAP & $10.1108 / 14691930710742844$ & 2007 & 17 & 69 \\
\hline TAN HP, 2007, J INTELLECT CAP & $10.1108 / 14691930710715079$ & 2007 & 34 & 223 \\
\hline TAN HP, 2008, J INTELLECT CAP & $10.1108 / 14691930810913177$ & 2008 & 19 & 96 \\
\hline
\end{tabular}




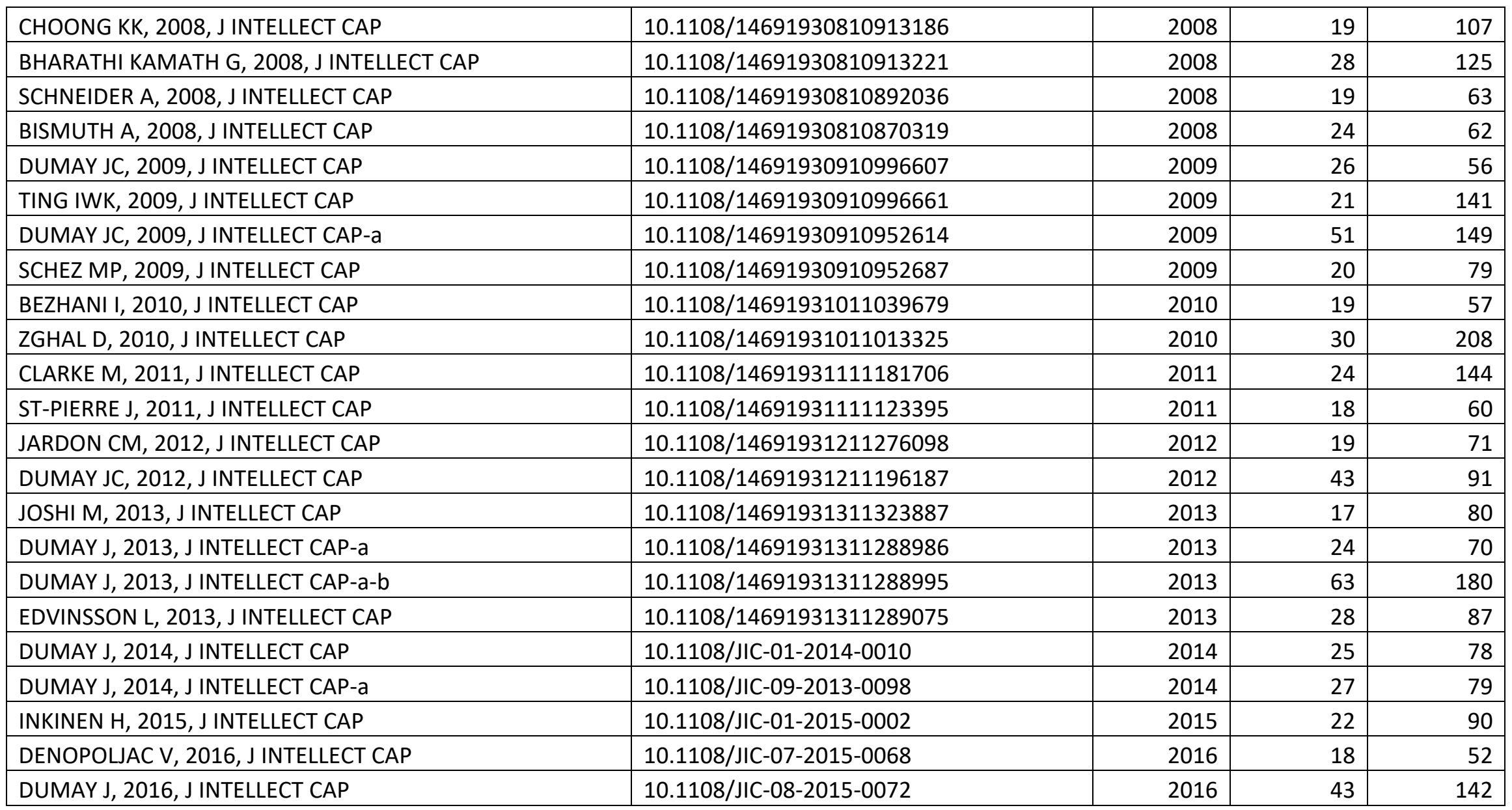


Figure 1: Publications trend over years

60

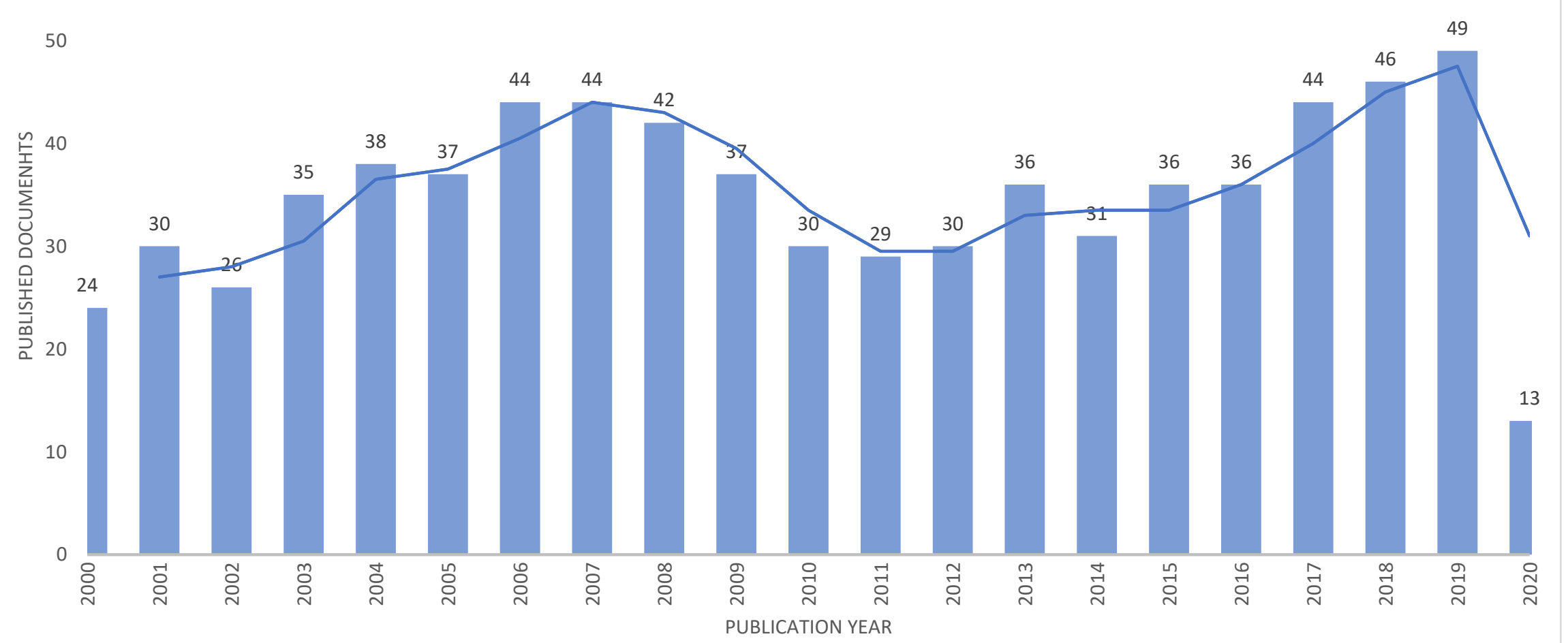




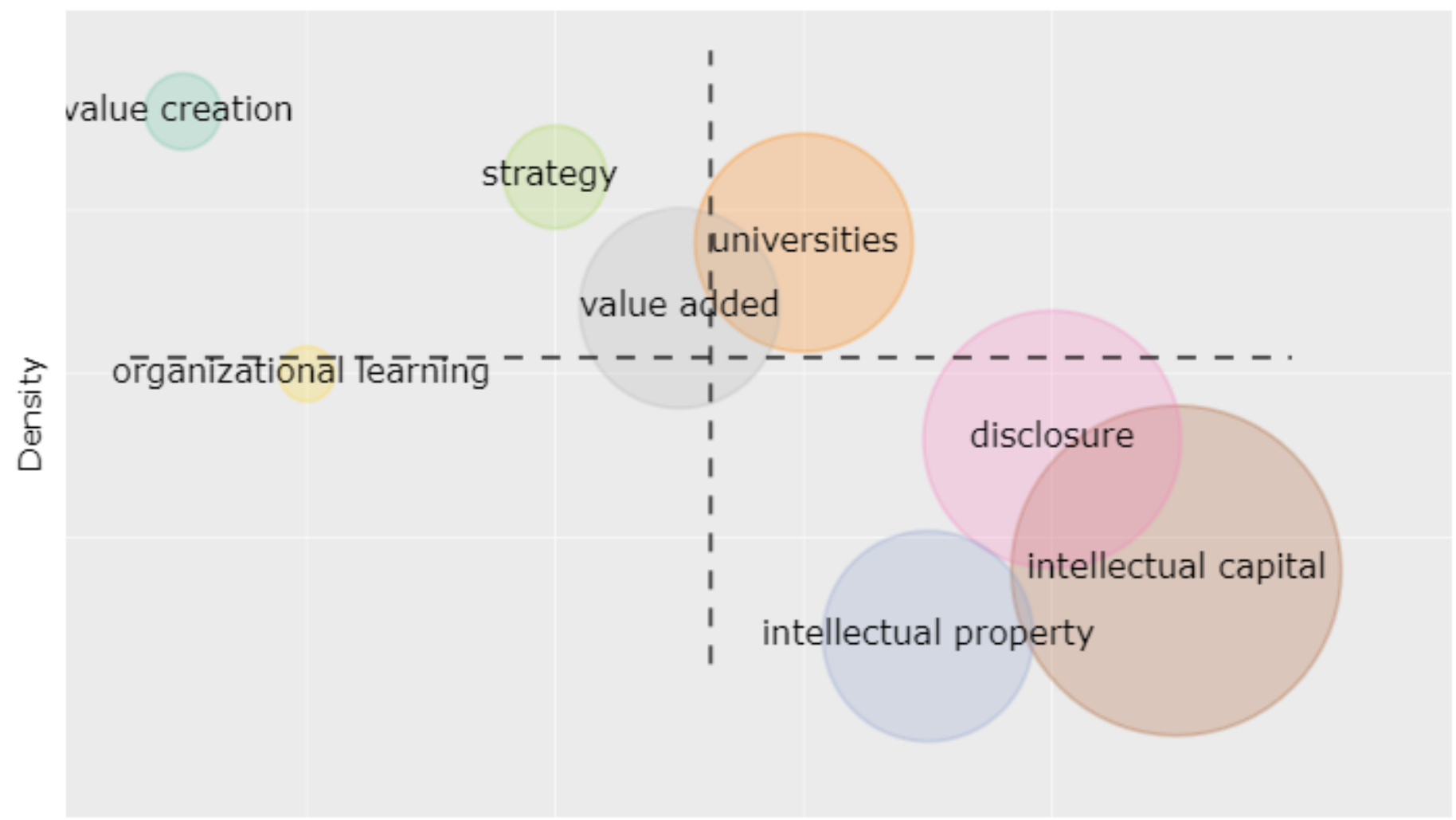

\section{Centrality}

Figure 2: Strategic Diagram of Conceptual Structure of JIC Scholarships 


\section{Historical Direct Citation Network}

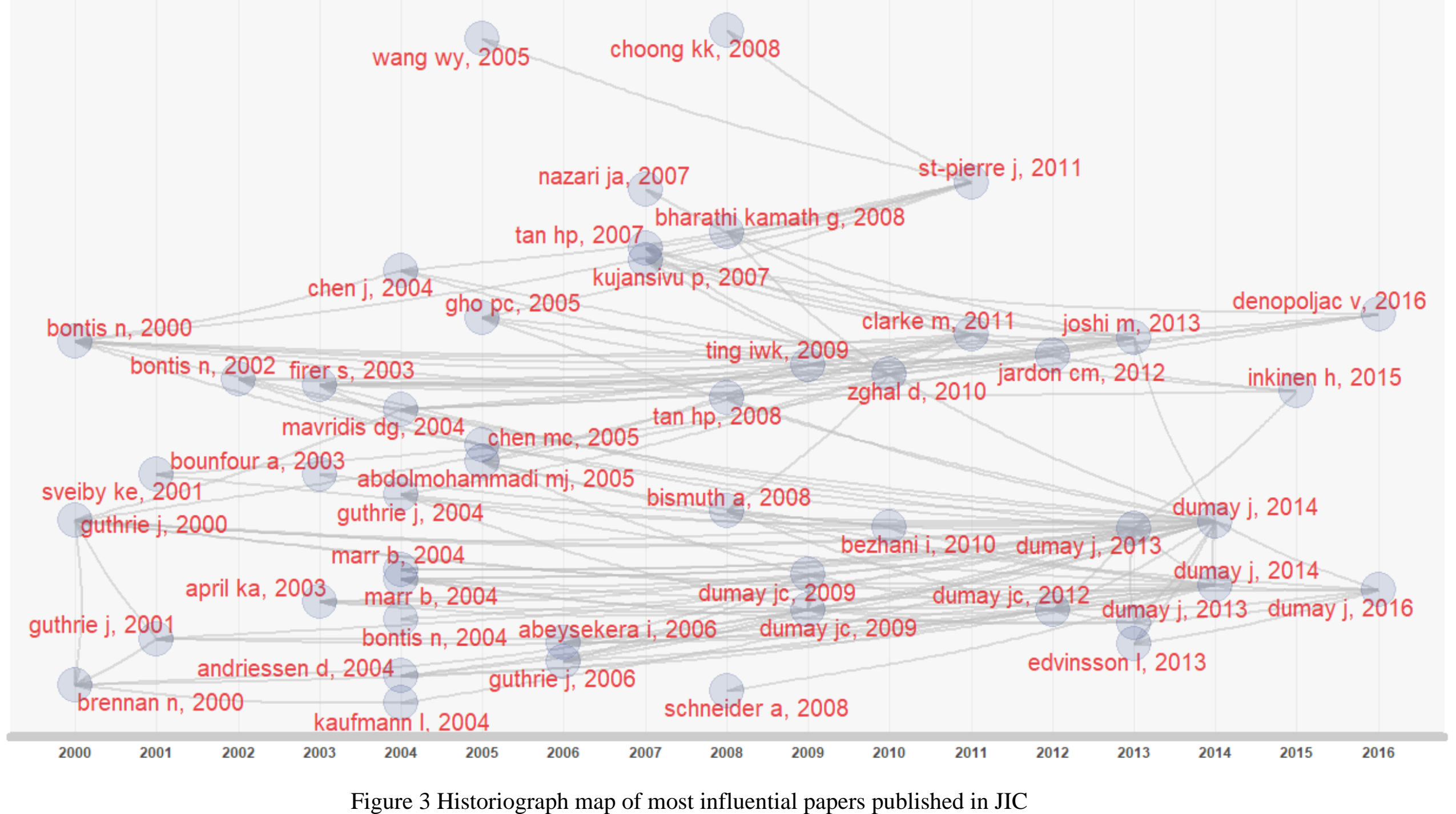

Figure 3 Historiograph map of most influential papers published in JIC 


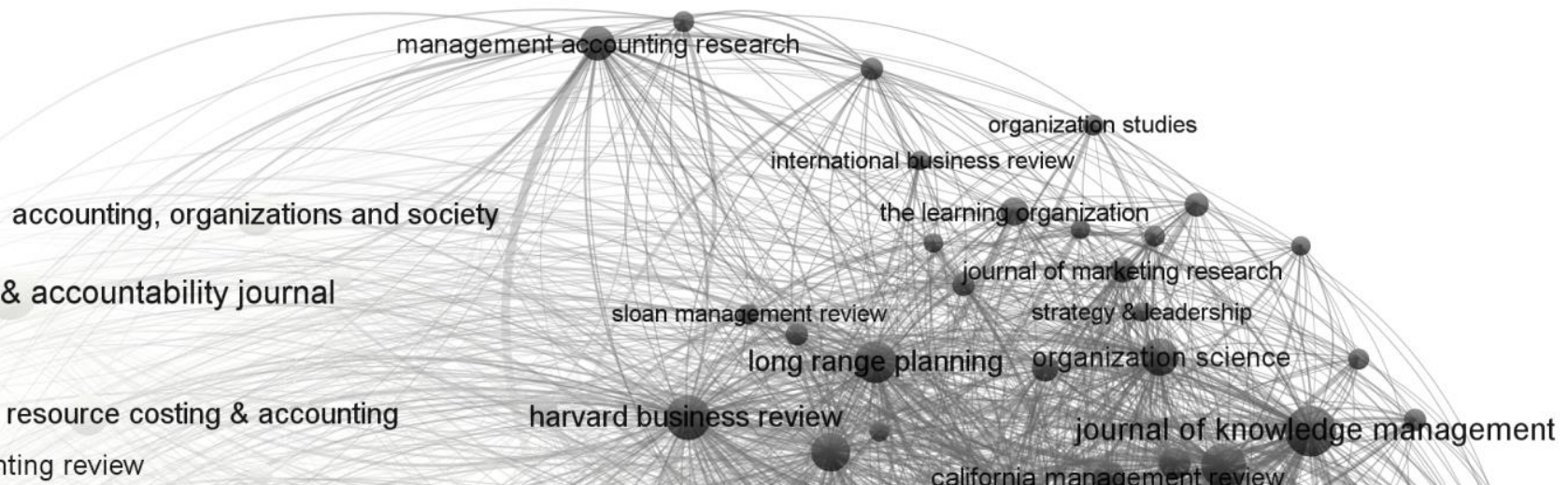

accounting, auditing \& accountability journa

australian accounting review

journal of human resource costing $\&$ accounting the british accounting review

harvard bus

$$
\text { journal of intellectual capital strategic managementjourna }
$$

european accounting review accounting and business research

the accounting review journal of accounting research

the international journal of accounting

$$
\text { journal of business ethics }
$$
management decision

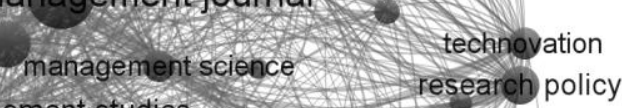

journal of management intellectual capital: realizing your company's true value by finding its hidden brainpower 1 small business economics journal of finance intangibles: management, measurement, and reporting journal of financial economics

$$
\text { international journal of learning and intellectual capital }
$$

the journal of finance african journal of business management ournal of business venturing

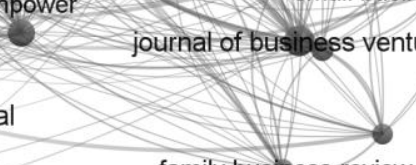

family business review

Figure 4 Co-citation network of top 100 linked sources in JIC 
clarke, m., seng, d., whiting, r.h., intellectual capital and firm performance in australia (2011) j

firer, s., williams, s.m. intellectual capital and traditional measures of corporate performance (2 bontis, n., intellectual capital: an exploratory study that develops measures and models (1998) mana

nahapiet, j., ghoshal, s., social capital, intellectual capital, and the organizational advantage (

mavridis, d.g., the intellectual capital performance of the japanese banking sector (2004) journal o

stahle, p., stahle, s. aho, s. value added intellectual coefficient (vaic): a critical analysis (2

kianto, a., what do we really mean by the dynamic dimension of intellectual capital? (2007) internat

brennan, n., connell, b. intellectual capital: current issues and policy implications (2000) journa

petty, r., guthrie, j., intellectual capital literature review: measurement, reporting and managemen

edvinsson, I., ic 21: reflections from 21 years of ic practice and theory (2013) journal of intellec

guthrie, j., ricceri, f., dumay, Ireflections and projections: a decade of intellectual capital a

dumay, j., intellectual capital measurement:

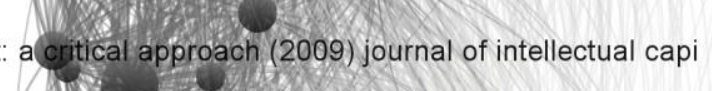

guthrie, j., petty, pontellectual capital: australian annual reporting practices (2000) journal o

guthrie, j., petty, r. yongvanich, k., ricceri, f., using content analysis as a research method to abeysekera, i., a template for integrated reporting (2013) journal of intellectual capital, 14 (2),

bozzolan, s., favotto, f., ricceri, f., italian annual intellectual capital disclosure: an empirical

striukova, I, unerman, j., guthrie, j., corporate reporting of intellectual capital: evidence from

beattie, v., thomson, s.j., lifting the lid on the use of content analysis to investigate intellectu

\& VOSviewer

Figure 5 Co-citation analysis of cited documents 


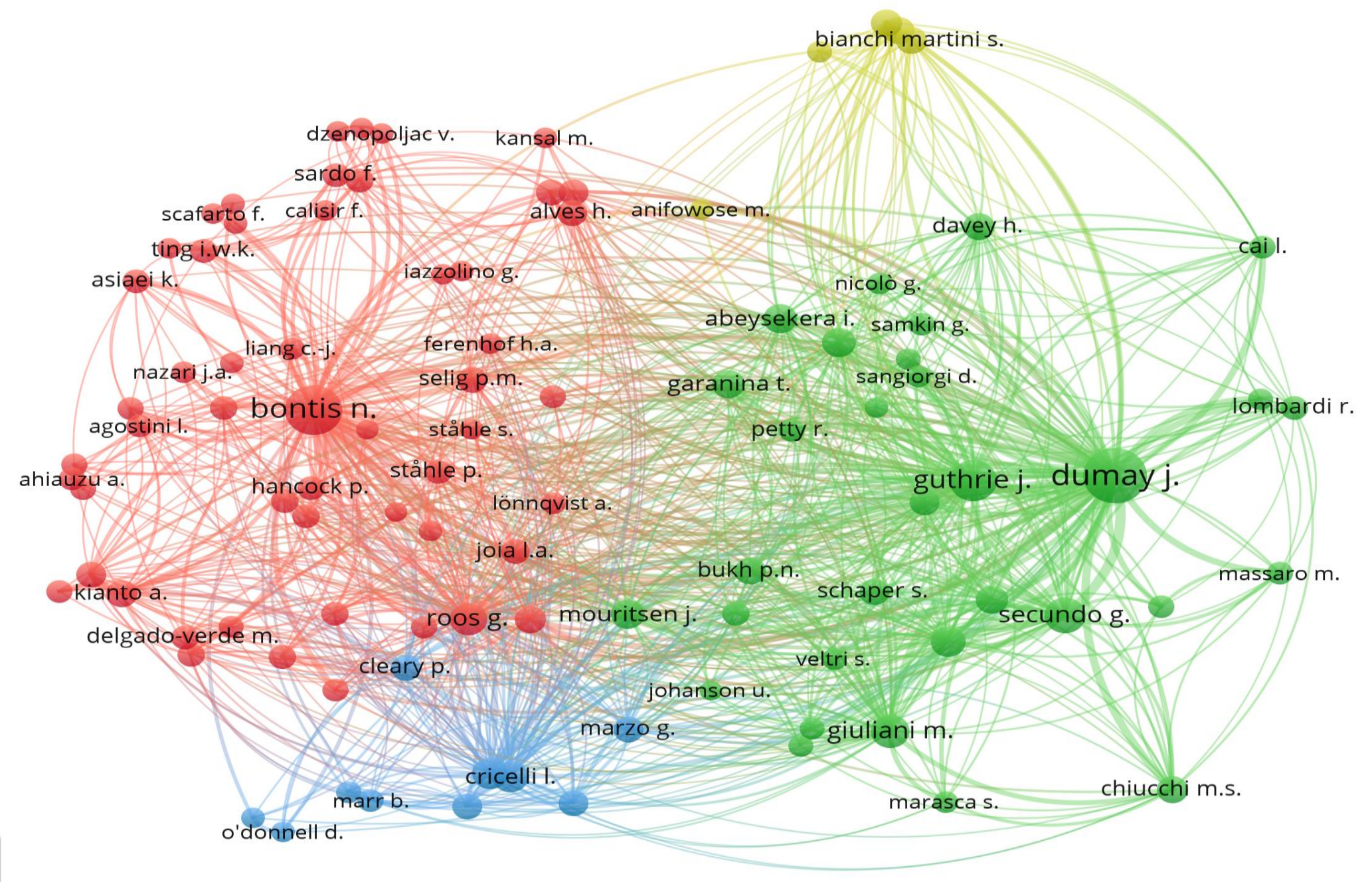

Figure 6 Bibliographic Coupling of Authors in JIC 


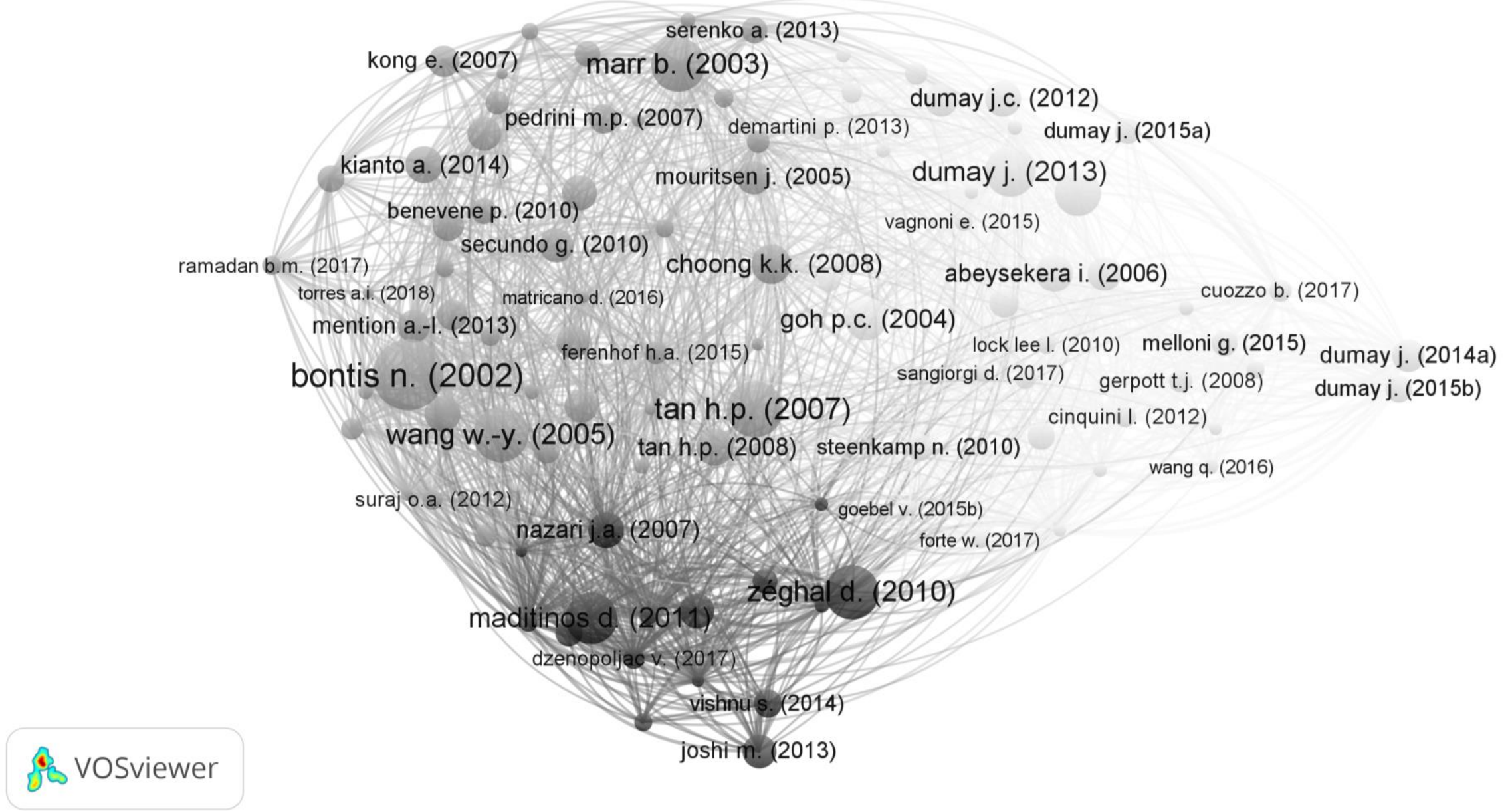

Figure 7 Bibliographic coupling of documents published in JIC 


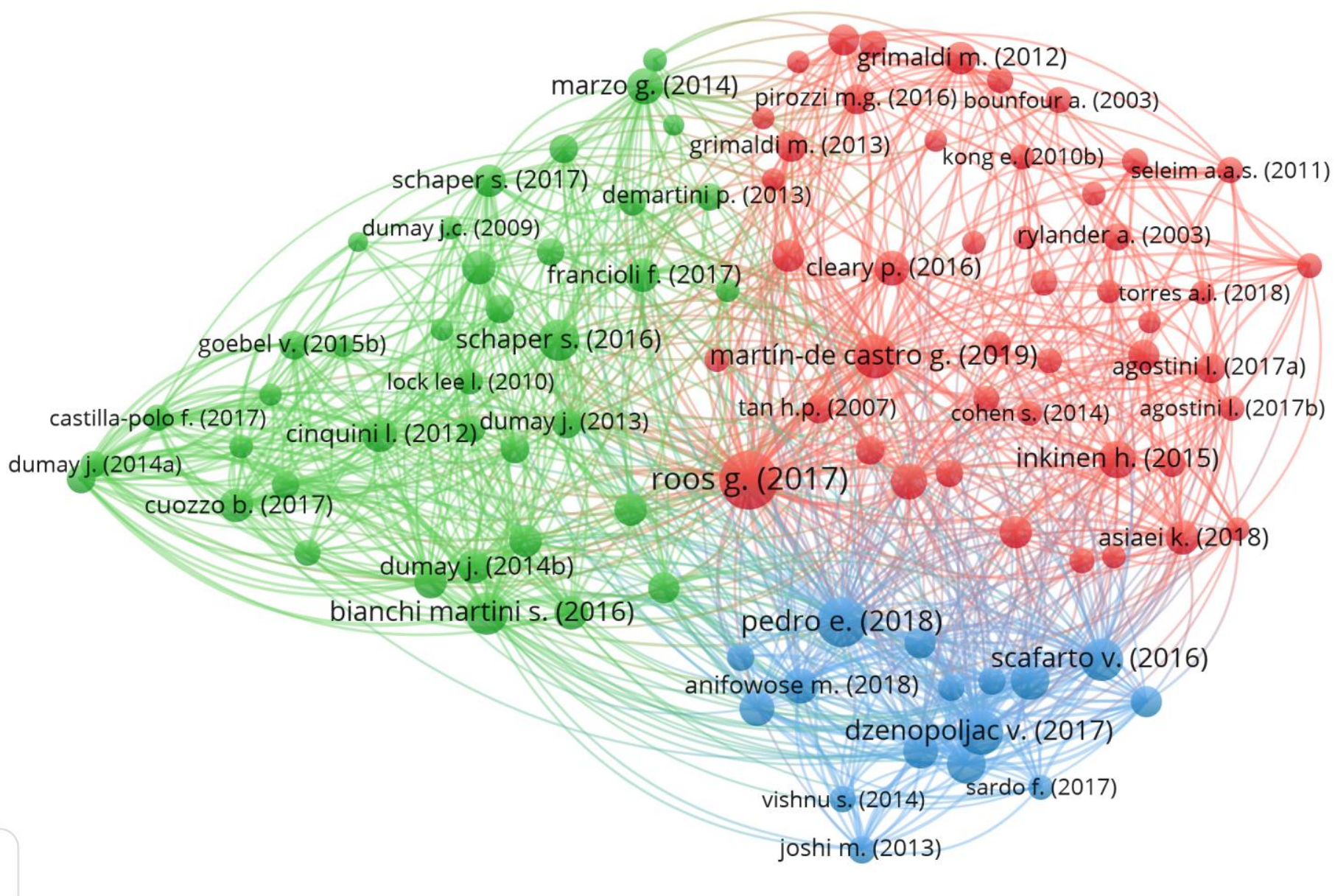

Figure 7 Bibliographic coupling of documents published in JIC 


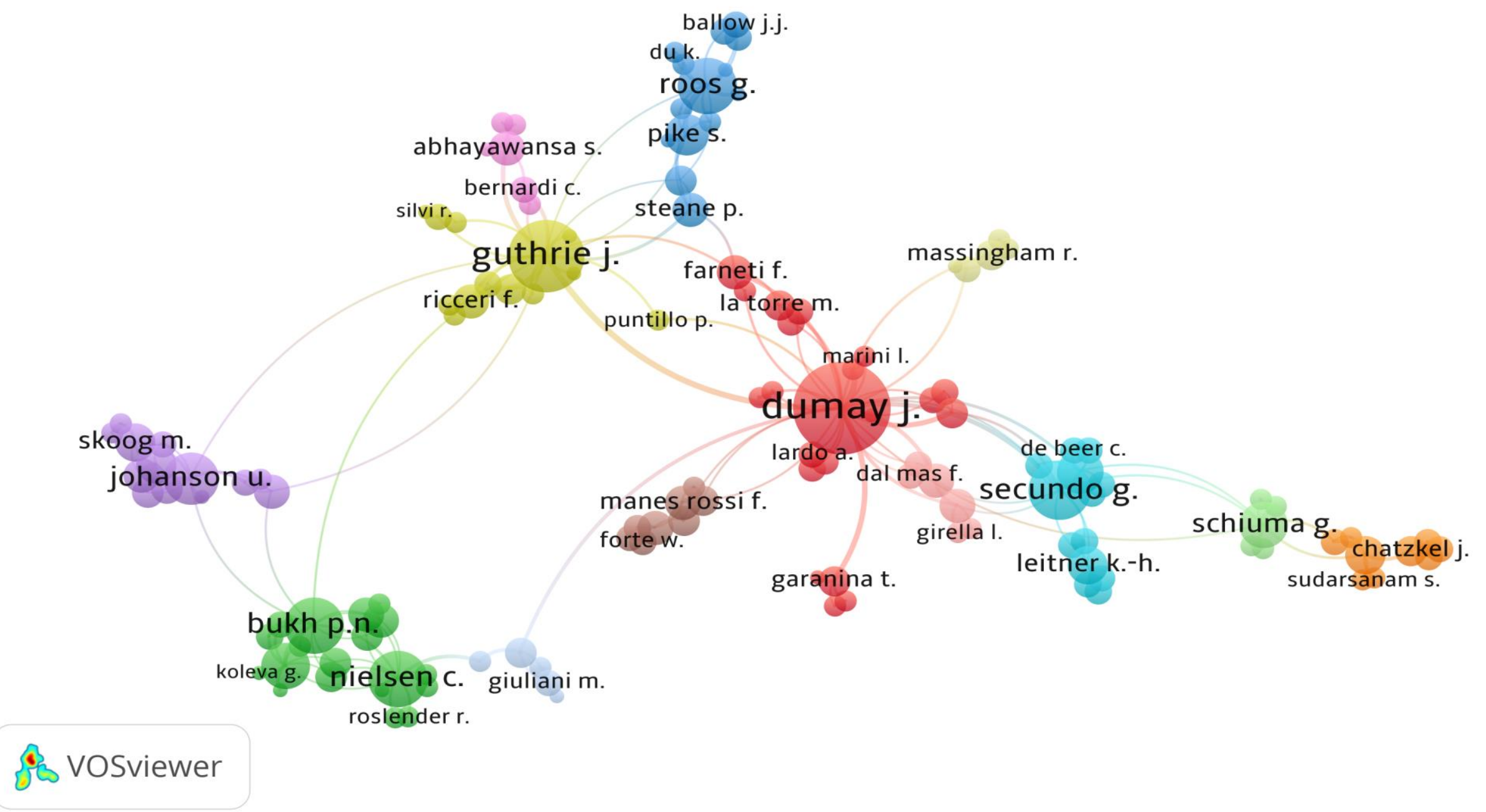

Figure 8 Collaboration network among authors in JIC 